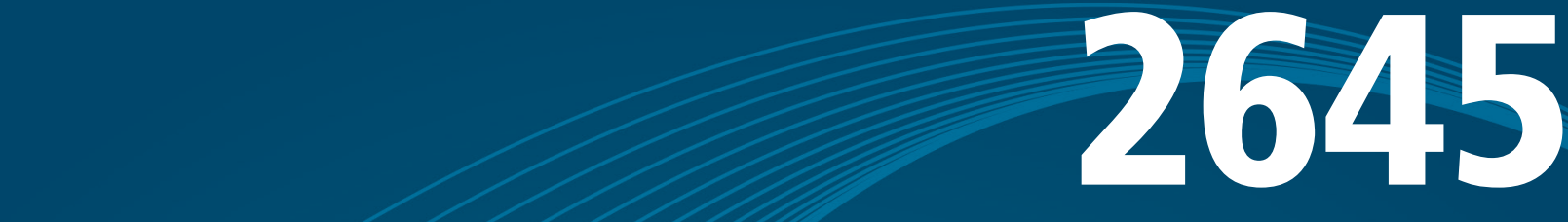

\title{
A PROGRESSIVIDADE DOS TRIBUTOS DIRETOS NAS PESQUISAS DE ORÇAMENTOS FAMILIARES (POFS) 2008-2009 E 2017-2018
}

\section{Pedro Humberto Bruno de Carvalho Junior}
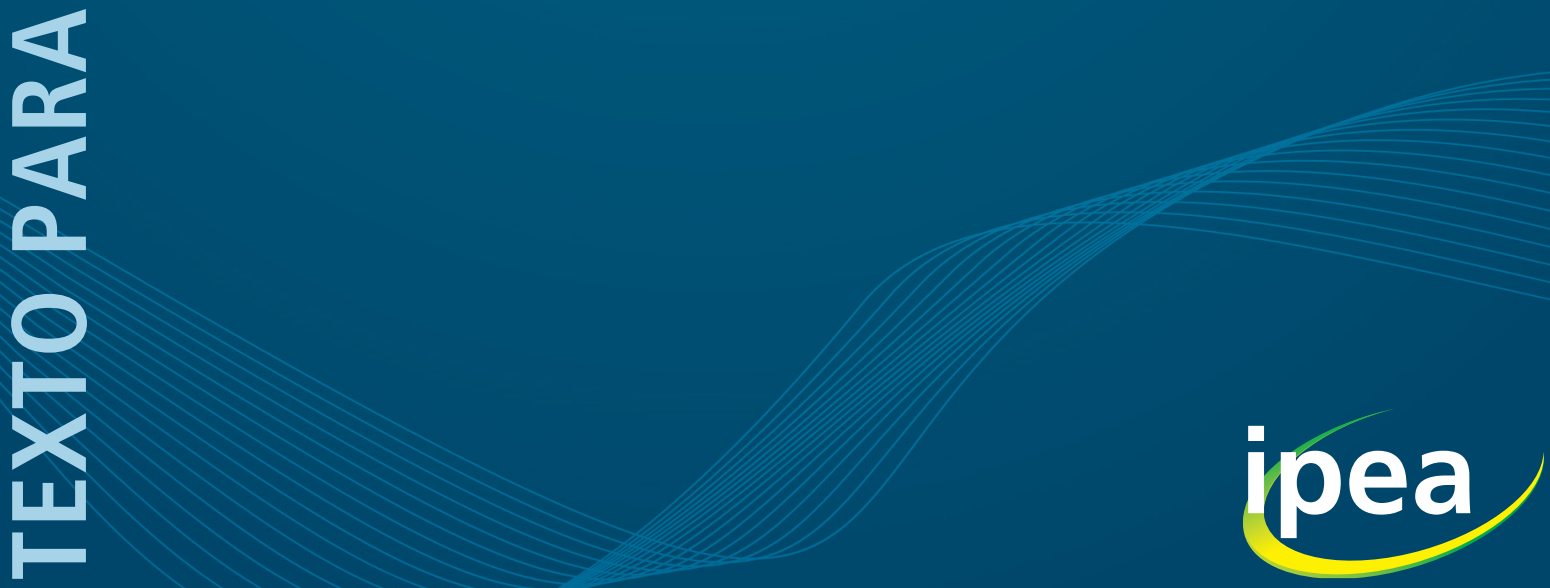



\section{TEXTO PARA DISCUSSÃO}

Rio de Janeiro, abril de 2021

A PROGRESSIVIDADE DOS TRIBUTOS DIRETOS NAS PESQUISAS DE ORÇAMENTOS FAMILIARES (POFs) 2008-2009 E 2017-2018

Pedro Humberto Bruno de Carvalho Junior ${ }^{1}$

1. Técnico de planejamento e pesquisa na Diretoria de Estudos e Relações Econômicas e Políticas Internacionais (Dinte) do Ipea. 


\section{Governo Federal}

Ministério da Economia

Ministro Paulo Guedes

\section{Texto para Discussão}

Publicação seriada que divulga resultados de estudos e pesquisas em desenvolvimento pelo Ipea com o objetivo de fomentar o debate e oferecer subsídios à formulação e avaliação de políticas públicas.

(C) Instituto de Pesquisa Econômica Aplicada - ipea 2021

Fundação pública vinculada ao Ministério da Economia o Ipea fornece suporte técnico e institucional às ações governamentais - possibilitando a formulação de inúmeras políticas públicas e programas de desenvolvimento brasileiros - e disponibiliza, para a sociedade, pesquisas e estudos realizados por seus técnicos.

Presidente

Carlos von Doellinger

Diretor de Desenvolvimento Institucional Manoel Rodrigues Junior

Diretora de Estudos e Políticas do Estado, das Instituições e da Democracia

Flávia de Holanda Schmidt

Diretor de Estudos e Políticas Macroeconômicas José Ronaldo de Castro Souza Júnior

Diretor de Estudos e Políticas Regionais, Urbanas e Ambientais

Nilo Luiz Saccaro Júnior

Diretor de Estudos e Políticas Setoriais de Inovação e Infraestrutura

André Tortato Rauen

Diretora de Estudos e Políticas Sociais

Lenita Maria Turchi

Diretor de Estudos e Relações Econômicas e

Políticas Internacionais

Ivan Tiago Machado Oliveira

Assessor-chefe de Imprensa e Comunicação André Reis Diniz

Ouvidoria: http://www.ipea.gov.br/ouvidoria

URL: http://www.ipea.gov.br

Texto para discussão / Instituto de Pesquisa Econômica Aplicada.- Brasília : Rio de Janeiro : Ipea, 1990-

ISSN 1415-4765

1.Brasil. 2.Aspectos Econômicos. 3.Aspectos Sociais. I. Instituto de Pesquisa Econômica Aplicada.

CDD 330.908

As publicações do Ipea estão disponíveis para download gratuito nos formatos PDF (todas) e EPUB (livros e periódicos).

Acesse: http://www.ipea.gov.br/portal/publicacoes

As opiniões emitidas nesta publicação são de exclusiva e inteira responsabilidade dos autores, não exprimindo, necessariamente, o ponto de vista do Instituto de Pesquisa Econômica Aplicada ou do Ministério da Economia.

É permitida a reprodução deste texto e dos dados nele contidos, desde que citada a fonte. Reproduções para fins comerciais são proibidas. 


\section{SUMÁRIO}

SINOPSE

ABSTRACT

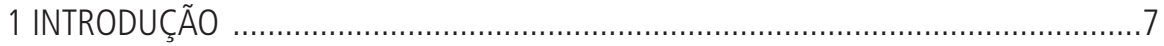

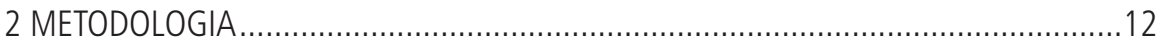

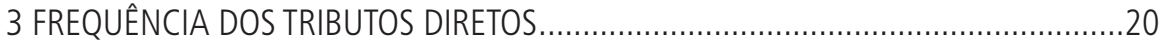

4 PARTICIPAÇÃO DOS TRIBUTOS DIRETOS NA RENDA DOMICILIAR ..........................30

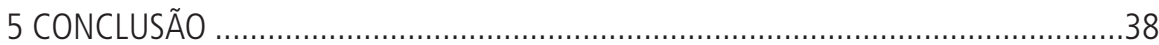

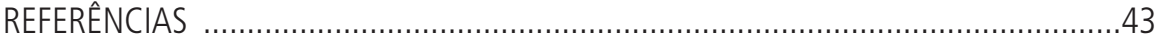

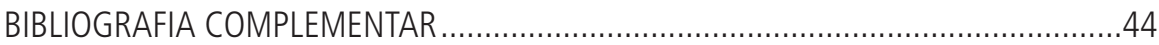





\section{SINOPSE}

Este trabalho analisou a distribuição da frequência e da participação na renda domiciliar de quatro tributos diretos nos domicílios brasileiros: Imposto Predial e Territorial Urbano (IPTU), Imposto sobre a Propriedade de Veículos Automotores (IPVA), Imposto de Renda de Pessoa Física (IRPF) sobre rendimentos do trabalho e contribuiçáo previdenciária por estratos de renda e geográfico com base nos dados das duas últimas pesquisas de orçamentos familiares (POFs) 2008-2009 e 2017-2018. O estudo constatou que o IRPF sobre rendimentos do trabalho foi progressivo em todos os estados de renda. O IPTU foi progressivo até os $9 \%$ mais ricos onde estabiliza sua participação na renda. O IPVA e a contribuição previdenciária foram regressivos devido ao crescimento recente da propriedade de veículos entre os mais pobres e ao limite máximo da contribuição previdenciária do Regime Geral de Previdência Social (RGPS) para rendas superiores ao teto previdenciário, respectivamente. Por fim, o estudo faz algumas propostas para reforma tributária de forma a tornar esses tributos mais progressivos.

Palavras-chave: tributos diretos; IPTU; IPVA; Imposto de Renda; contribuição previdenciária; Pesquisa de Orçamentos Familiares; progressividade tributária.

\section{ABSTRACT}

This study analyzes the distribution of frequency and income share of four direct taxes among Brazilian households - property tax, vehicle tax, personal income tax on labor income, and social contributions - per income and geographical strata, based on the last two Household Budget Surveys of 2008-2009 and 2017-2018. The study found that property tax and labor income tax are progressive up to the $1 \%$ richest, which starts to decrease their ratio on household income. Vehicle tax and social contributions are regressive, mainly due to the recent increase of vehicles ownership among the poorer and the ceiling of the general social contributions among income above six minimum wages, respectively. Finally, this study makes some proposes to the tax reform to enhance progressivity.

Keywords: direct taxes; property tax; vehicle tax; personal income tax; social contribution; household budget survey; tax progressivity. 



\section{INTRODUÇÃO}

Desde 2020, foram realizadas apenas seis pesquisas de orçamentos familiares (POFs) no Brasil, o Estudo Nacional de Despesa Familiar (Endef) 1974-1975 e as POFs de 1987-1988, 1995-1996, 2002-2003, 2008-2009 e 2017-2018. A primeira Endef 1974-1975 teve âmbito nacional, mas as duas POFs posteriores, realizadas em 1987/1988 e em 1995-1996, incluíram apenas as nove principais regióes metropolitanas (RMs) da época (Porto Alegre, Curitiba, São Paulo, Rio de Janeiro, Belo Horizonte, Salvador, Recife, Fortaleza e Belém), além de Goiânia e do Distrito Federal. Já as três últimas edições da POF (2002-2003, 2008-2009 e 2017-2018), além de terem sido realizadas para todo o Brasil, urbano e rural, trazem adicionalmente medidas antropométricas, como peso e altura dos indivíduos.

$\mathrm{Na}$ maioria dos países as pesquisas de despesas familiares ocorrem em intervalos menores que no Brasil (mesmo que estas pesquisas sejam mais simples e possuam uma amostra menor), podendo ser anual (Canadá, ${ }^{1}$ Espanha, ${ }^{2}$ Estados Unidos, ${ }^{3}$ Inglaterra, ${ }^{4}$ Rússia $^{5}$ e Suécia ${ }^{6}$ ), bianual (Argentina, ${ }^{7}$ México $^{8}$ e Itália ${ }^{9}$ ), quinquenal (África do Sul, ${ }^{10}$ Alemanha, ${ }^{11}$ Chile, $^{12}$ Índia, ${ }^{13}$ França $^{14}$ e Japão ${ }^{15}$ ), ou a cada seis anos (Austrália ${ }^{16}$ ).

1. Survey of Household Spending (SHS/Statistics Canada - StatsCan), amostra aproximada de 18 mil domicílios.

2. Encuesta de Presupuestos Familiares (EPF/Instituto Nacional de Estadísticas - INE), amostra aproximada de 24 mil domicílios.

3. Consumer Expenditure Survey (CEX/Bureau of Labor Statistics - BLS), amostra aproximada de 20 mil domicílios.

4. Living Costs and Food Survey (LCF/Office for Nacional Statistics - ONS), amostra aproximada de 6 mil domićlios.

5. Household Budget Survey (HBS/Federal State Statistics Service - Rosstat), amostra aproximada de 50 mil domicílios.

6. Swedish Household Budget Survey (HBS/Statistics Sweden - SCB), amostra aproximada de 2 mil domicílios.

7. Encuesta Nacional de Gastos de los Hogares (ENGHo/Instituto Nacional de Estadística y Censos - Indec), amostra aproximada de 45 mil domicílios.

8. Encuesta Nacional de Ingresos y Gastos de los Hogares (Enigh/Instituto Nacional de Estadística y Geografía - Inegi), amostra aproximada de 80 mil domicílios.

9. Survey on Household Income and Wealth (SHIW/Bank of Italy), amostra aproximada de 8 mil domicílios.

10. Income and Expenditure Survey (IES/Statistics South Africa - StatsSA), amostra aproximada de 25 mil domicílios.

11. Sample Survey of Income and Expenditure (EVS/Statistisches Bundesamt - DEstats), amostra aproximada de 60 mil domicílios.

12. Encuesta de Presupuestos Familiares (EPF/INE), amostra aproximada de 25 mil domicílios.

13. Household Expenditure on Services and Durable Goods (HESDG/Ministry of Statistics and Programme Implementation Mospi), amostra aproximada de 83 mil domićlios.

14. Household Budget Survey (BDF/Institut National de la Statistique et des Études Économiques - Insee), amostra aproximada de 29 mil domicílios.

15. National Survey of Family Income and Expenditure (NSFIE/Statistics Bureau of Japan - SBJ), amostra aproximada de 57 mil domicílios.

16. Household Expenditure Survey (HES/Australian Bureau of Statistics - ABS), amostra aproximada de 10 mil domicílios. 
No entanto, no Peru $^{17}$ e na Colômbia ${ }^{18}$ as pesquisas de despesas familiares têm se realizado apenas em intervalos de dez anos.

No Brasil, devido ao alto custo de execução, a pesquisa tem tido frequência variável, visto que os intervalos entre as cinco POFs foram oito anos, sete anos, seis anos e nove anos, respectivamente com uma amostra de cerca de 50 mil domicílios nas três últimas POFs. Por outro lado, as pesquisas possuem uma alta e excelente quantidade de informaçóes que mostram de forma eficaz o padrão de vida das famílias brasileiras. Apesar da quantidade das POFs executadas no Brasil ser baixa quando comparadas com outras pesquisas como a Pesquisa Nacional por Amostra de Domicílios (PNAD), é bastante ampla a possibilidade de estudos de demanda e consumo derivado da pesquisa, principalmente de alimentos, como os trabalhos de Almeida (2011), Hoffmann (2006; 2007), Silveira et al. (2006; 2007).

A base de dados utilizada neste trabalho são a POF 2008-2009 realizada pelo Instituto Brasileiro de Geografia e Estatística (IBGE) entre maio de 2008 e maio de 2009, abrangendo uma amostra de 55.970 domicílios, e principalmente a POF 2017-2018 realizada pelo IBGE entre julho de 2017 a julho de 2018, abrangendo uma amostra de 57.920 domicílios. A definição da amostragem nessas duas pesquisas e os fatores de expansão dos pesos dos domicílios se basearam nos censos demográficos de 2000 e 2010, respectivamente. A POF 2017-2018 apresenta sete questionários.

O primeiro questionário possui informações sobre as características do domicílio e de seus moradores, como a forma de abastecimento de água, tipo de esgotamento sanitário, número de cômodos, além do número de famílias (unidades de consumo) residindo no mesmo espaço domiciliar, e características do indivíduo (grau de instrução, peso, altura, posição na família etc.).

O segundo questionário apresenta as despesas coletivas do domicílio, como despesa com energia elétrica, telefonia fixa e internet, aluguel e condomínio, Imposto Predial e Territorial Urbano (IPTU), material de construção e peças de manutenção, bens duráveis

17. Encuesta Nacional de Presupuestos Familiares (Enapref/Instituto Nacional de Estadística e Informática - Inei), amostra aproximada de 40 mil domicílios.

18. Encuesta Nacional de Presupuestos de los Hogares (ENPH/Departamento Administrativo Nacional de Estadística Dane), amostra aproximada de 90 mil domicílios. 
e eletrônicos, despesa com animais de estimação, pagamento de serviços domésticos etc. Além disso, o questionário levanta informaçōes sobre o inventário de bens duráveis do domicílio e ano de aquisição, como por exemplo, automóveis e motocicletas.

O terceiro questionário apresenta as despesas com produtos alimentares, higiene e limpeza pelas unidades de consumo.

O quarto questionário apresenta as despesas com itens de consumo individual, como fumo, loteria, meios de transporte, combustível, alimentação fora de casa, correios, despesas bancárias, livros e revistas, ingressos diversos, bares, academias, medicamentos, médicos e planos de saúde, produtos de higiene e limpeza, material de escritório e escolar, bicicleta, vestuário, automóvel e Imposto sobre a Propriedade de Veículos Automotores (IPVA), escolas e cursos, conta de telefonia celular, carnê-leão do imposto de renda e contribuição previdenciária de autônomos etc.

O quinto questionário apresenta os rendimentos brutos mensais habituais do trabalho e as respectivas deduçóes na fonte com Imposto de Renda de Pessoa Física (IRPF), contribuiçóes previdenciárias, Imposto sobre Serviços (ISS) e "outras deduçóes", além do tempo de deslocamento casa para trabalho, classificação e condiçóes emprego, horas trabalhadas por semana etc. $\mathrm{O}$ quinto questionário também apresenta outros tipos de rendimentos, como aposentadorias e pensões, programas assistenciais, décimo terceiro salário e férias, participação nos lucros e comissóes, horas extras e bônus, renda de aluguéis e aplicações financeiras etc. Porém, no caso de rendimentos não derivados do trabalho, a POF mostra apenas o valor global da dedução na fonte desses rendimentos, não especificando se essa dedução foi IRPF, contribuição previdenciária ou ISS, como ocorre nos rendimentos do trabalho.

O questionário 6 avalia a percepção da condição de vida dos respondentes, como domicílios insalubres e com externalidades negativas (violência, poluição etc.), dificuldades financeiras e atraso/inadimplência no pagamento de contas dos moradores, carência nutricional e sentimento de fome etc.

Por fim o questionário 7 trata das características da dieta e da saúde dos respondentes, como calorias ingeridas, tipos de refeições, problemas de saúde como obesidade, diabetes e hipertensão etc. 
Na União Europeia, as POFs foram harmonizadas em 2011. Aguiar e Bills (2011), analisando as despesas das famílias americanas entre 1980 e 2007, verificaram que a inequidade de renda e consumo tendem a ser similares, caso seja corrigida a subdeclaração da despesa com bens de alto valor. Além disso, os autores verificaram uma pequena, embora maior mensuraçáo do consumo nas classes mais pobres se comparado com a renda. Koijen, Nieuwerburgh e Vestman (2015) também verificaram que a aquisição de capital e bens luxuosos é subestimada na pesquisa orçamentária da Suécia, enquanto que o consumo das classes de menor renda é levemente superestimado. Já Meyer, Mok e Sullivan (2009) constataram que a renda de transferência de programas sociais é subdeclarada nas pesquisas orçamentárias nos Estados Unidos gerando uma despesa orçamentária maior que prevista. Em oposição, os autores constataram uma subdeclaração da despesa média de $24 \%$ no quintil dos mais ricos, sendo que $30 \%$ da aquisição de veículos não eram reportadas.

Rossignolo (2016), usando dados da Pesquisa de Renda e Despesa Domiciliar de 2012/2013 da Argentina analisa o impacto da tributação e do gasto público na distribuição de renda e pobreza. $\mathrm{O}$ autor conclui que a política de programas assistenciais tem alto impacto na redução da iniquidade e pobreza, porém seu uso mais acentuado é limitado pela restriçáo orçamentária. Na tributação, o autor analisou os tributos diretos (IRPF, contribuiçóes sociais sobre salários etc.) e indiretos (Imposto sobre o Valor Agregado - IVA, impostos sobre o faturamento, Imposto sobre Combustíveis etc.), e constatou que os dois quintos mais altos de renda transferem recursos para os mais baixos através da tributação.

Surico e Trezzi (2019), utilizando dados de pesquisas orçamentárias, estudaram a tributação de imóveis residenciais na Itália. Para 2012, eles verificaram que os imóveis representavam $65 \%$ do estoque de riqueza das famílias italianas e que o imposto imobiliário era pago por 70\% dos domicílios, consumindo em média 1,2\% da renda dos que eram proprietários de um único imóvel (pois possuíam um sistema de tributação mais favorável) e 3\% da renda das famílias proprietárias de mais de um imóvel.

No Brasil, Carvalho Junior (2009) analisou a distribuição do valor do patrimônio imobiliário residencial das famílias brasileiras (com base nos aluguéis pagos e imputados na POF 2002-2003 e a sua consequente tributação pelo IPTU. O autor constatou que a distribuição da renda domiciliar e do patrimônio imobiliário residencial se 
comportavam de maneira similar por estratos de renda, embora os imóveis residenciais sejam apenas uma parte da riqueza domiciliar que também é composta por ativos financeiros. A tributação pelo IPTU foi progressiva considerando-se todos os domicílios brasileiros, pois apenas 30\% eram pagantes do imposto. Porém, o nível de tributação era extremamente regressivo caso se analisasse apenas o universo de contribuintes do imposto. Por fim, o autor concluiu que avaliaçôes imobiliárias menos regressivas realizadas pelas prefeituras e uma maior progressividade das alíquotas poderia reduzir o viés regressivo do IPTU. Tal comportamento também foi verificado pelo mesmo autor em trabalho posterior para o caso do IPVA (Carvalho Junior, 2018a).

Mais recentemente, Silveira et al. (2020) analisaram o impacto distributivo entre décimos de renda dos tributos diretos na POF 2017-2018. Os autores verificaram que o IPTU tem perfil relativamente proporcional, representando ao redor de $0,6 \%$ da despesa das famílias em todos os décimos de renda, o IPVA e as contribuiçóes previdenciárias tem perfil regressivo quando comparado o último décimo de renda com os décimos intermediários, e o IRPF tem perfil progressivo.

Portanto, baseado no trabalho anterior de Carvalho Junior (2009), este estudo almeja avaliar o nível de progressividade ou regressividade dos tributos diretos entre os domicílios brasileiros utilizando dados da POF, desta vez considerando as despesas com os quatro principais tributos diretos computados pela pesquisa: IPTU, IPVA, IRPF sobre rendimentos do trabalho e contribuição previdenciária. A principal limitação deste estudo, é que devido ao grau de detalhamento dos dados nas duas POFs, só se é possível extrair com precisão a dedução na fonte do IRPF incidente sobre rendimentos do trabalho, bem como estimar o IRPF incidente sobre aposentadorias, pensóes e o décimo terceiro salário através da aplicação da tabela padrão do IRPF na fonte, deixando de fora os rendimentos tributáveis de capital que possuem regras de tributação complexas. Com isso, a carga tributária no topo da renda, apesar da isenção para lucros e dividendos e do tratamento favorável para renda financeira, estará subestimada.

Este estudo está dividido em cinco seçóes, incluindo esta introdução. A segunda mostra a metodologia, analisando as amostras das POFs 2008-2009 e 2017-2018 e delimitando oito estratos de renda domiciliar e quinze estratos geográficos, além de validar os dados através da comparação entre o total da despesa com os tributos diretos nas duas POFs e suas respectivas arrecadaçóes tributárias nos anos de 2009 e 2018. 
A terceira seção analisa a frequência (percentual de domicílios contribuintes) dos tributos analisados por estrato de renda e geográfico, além da frequência de benefícios da seguridade social. A quarta seção analisa a participação dos tributos diretos na despesa domiciliar considerando o universo de todos os domicílios brasileiros e apenas os domicílios pagantes dos respectivos tributos, como forma de avaliar o padrão de progressividade causada pelo desenho da legislação e pela administração tributária perante os contribuintes. Por fim, a quinta seção trata das conclusóes do estudo, fazendo um diagnóstico da distribuição da carga tributária direta através dos dados levantados na POF, formulando algumas proposiçóes de política para aumentar o grau de progressividade da tributação direta no Brasil e tecendo as consideraçóes finais.

\section{METODOLOGIA}

Essa segunda seção discute a metodologia utilizada para extração dos dados da POF e a validação dos dados com despesa em tributos diretos e as suas respectivas arrecadaçóes tributárias.

\subsection{Delimitação dos estratos de renda domiciliar e geográfico}

A POF 2017-2018 possui uma amostra representativa de 57.999 domicílios que reflete um universo de 68,76 milhóes de domicílios brasileiros. Este estudo analisa a tributação direta entre os domicílios brasileiros em dois estratos: por faixa de renda e por estrato geográfico. A análise por faixa de renda se justifica para verificar o nível de progressividade da tributação direta enquanto a análise geográfica permite verificar algum viés regional na tributação.

Diniz et al. (2007) realizaram diversas comparações entre os dados da POF 2002/2003 e das PNADs 2002 e 2003, não encontrando nenhuma discrepância significativa entre as pesquisas, o que confirma o bom desenho da amostra da POF. Os autores também não encontraram discrepância quando compararam os dados da POF 2002-2003 e os dados administrativos dos benefícios previdenciários do Regime Geral de Previdência Social (RGPS) e Regime Próprio de Previdência Social (RPPS).

A tabela 1 a seguir compara o coeficiente do Gini e a participação per capita na renda total dos 10\% e 1\% mais ricos e dos 40\% mais pobres, não encontrando nenhuma 
discrepância significativa entre as POFs 2008-2009 e 2017-2018 e as PNADs 2009 e 2018, respectivamente.

TABELA 1

Coeficiente de Gini e medidas de concentração per capita na renda total nas POFs e nas PNADs

\begin{tabular}{|c|c|c|c|c|}
\hline & \multicolumn{2}{|c|}{ POF } & \multicolumn{2}{|c|}{ PNAD } \\
\hline & $2002-2003$ & 2017-2018 & 2009 & 2018 \\
\hline Gini & 0,561 & 0,535 & 0,516 & 0,541 \\
\hline $10 \%$ mais ricos $(\%)$ & 44,4 & 42,7 & 42,7 & 42,5 \\
\hline $1 \%$ mais ricos $(\%)$ & 12,8 & 12,5 & 12,1 & 12,0 \\
\hline $40 \%$ mais pobres (\%) & 9,6 & 10,8 & 10,7 & 10,0 \\
\hline
\end{tabular}

Fonte: IBGE, microdados das POFs 2008-2009 e 2017-2018 e das PNADs 2009 e 2018 (renda efetiva).

Elaboração do autor.

Este estudo dividiu os domicílios da POF 2017-2018 em oito faixas de renda domiciliar, representando múltiplos do salário mínimo (SM) nominal de 2018 (R \$ 954). Os dados da POF 2017/2018 são também comparados com os dados da POF 2008-2009, porém não será levado em consideração o SM vigente em 2009, devido ao seu significativo aumento real, mas somente a faixa de percentil de renda domiciliar correspondente à faixa de SM fixada na POF 2017-2018. Ou seja, se na POF 2017-2018 a renda de um SM de 2018 correspondia ao percentil 5,8 de distribuição da renda, esse percentil será comparado com o dado da POF 2008-2009 (e náo com o valor do SM vigente em 2009).

A tabela 2 apresenta os oito estratos de renda definidos por este estudo nas POFs 2008-2009 e 2017-2018, a renda média em cada estrato, e o número do universo e da amostra contidos em cada um. A tabela apresenta a renda domiciliar total, que inclui a renda monetária e não monetária (esta última representando as doaçôes e transferências em espécie, presentes e/ou serviços).

De acordo com a tabela 2, em 2017-2018, as famílias com renda total de até 2 SMs representavam quase um quarto dos domicílios brasileiros (percentil 24,1), as famílias com renda total de até 3 SMs representavam 43\% dos domicílios e as de renda até 5 SMs representavam dois terços dos domicílios brasileiros. Por outro lado, apenas 4,6\% das famílias possuíam renda domiciliar total superior a $18 \mathrm{SMs}$ de $2018(\mathrm{R} \$ 17.172)$. 
TABELA 2

POF 2017-2018 e 2008-2009: característica dos estratos de renda domiciliar total mensal delimitados pelo estudo

\begin{tabular}{|c|c|c|c|c|c|c|}
\hline \multirow{2}{*}{ Faixa de percentil } & \multicolumn{4}{|c|}{ POF 2017/2018 } & \multicolumn{2}{|c|}{ POF 2008/2009' } \\
\hline & Faixa de SM (2018) & Renda média (R\$) & Domicílios amostra & Domicilios total & Domicílios amostra & Domicilios total \\
\hline 5,8 & Até 1 & 630 & 4.173 & 3.964 .154 & 4.273 & 3.489 .764 \\
\hline 24,1 & $1-2$ & 1.453 & 12.254 & 12.623 .458 & 13.432 & 11.267 .424 \\
\hline 43,1 & $2-3$ & 2.389 & 11.816 & 13.055 .507 & 10.927 & 10.363 .658 \\
\hline 66,6 & $3-5$ & 3.705 & 13.523 & 16.157 .605 & 12.873 & 13.507 .091 \\
\hline 90,9 & $5-12$ & 7.095 & 12.140 & 16.723 .230 & 10.926 & 13.844 .306 \\
\hline 95,4 & $12-18$ & 13.859 & 2.020 & 3.095 .165 & 1.833 & 2.561 .474 \\
\hline 98,8 & $18-36$ & 23.123 & 1.436 & 2.325 .183 & $1 ; 282$ & 1.995 .783 \\
\hline 100,0 & Mais de 36 & 57.060 & 437 & 817.116 & 424 & 662.281 \\
\hline $0-100$ & Total & 5.437 & 57.799 & 68.761 .418 & 55.970 & 57.691 .781 \\
\hline
\end{tabular}

Fonte: IBGE, microdados da POF 2008-2009 e 2017-2018.

Elaboração do autor.

Nota: 1 Os dados de 2008/2009 são referentes apenas a faixa de percentil indicado, e não ao SM.

Obs.: SM de $2018=$ R\$ 954.

Além dos estratos de renda, este estudo definiu quinze estratos regionais para analisar o grau de variabilidade regional dos indicadores de tributaçáo direta. Foram três diferentes situaçóes de domicílios: i) os domicílios localizados na zona urbana das capitais e RMs; ii) domićlios localizados em zonas urbanas do interior; e iii) domicílios localizados em zona rural. Dentro de cada uma dessas três situaçôes de domicílio, delimitaram-se cinco estratos geográficos representando as cinco Grandes Regiốes. A tabela 3 mostra os dados amostrais dos quinze estratos geográficos.

De acordo com a tabela 3, na POF 2017-2018, todos os quinze estratos regionais possuem uma amostra maior que 1.700 domicílios. Os domicílios das capitais e RMs representaram 34\% da amostra da POF 2017-2018; os do interior urbano, 43\%; e os da zona rural, $23 \%$. No entanto, considerando-se o universo, isto é, levando-se em consideração o peso de cada domicílio na amostra, esses percentuais são respectivamente: $37 \%, 48 \%$ e $15 \%$. 
TABELA 3

POF 2017-2018 e 2008-2009: característica dos estratos geográficos delimitados pelo estudo

\begin{tabular}{|c|c|c|c|c|c|}
\hline \multirow{2}{*}{ Situação } & \multirow{2}{*}{ Grande Região ou estado(s) } & \multicolumn{2}{|c|}{ Domicílios da amostra } & \multicolumn{2}{|c|}{ Domicílios do universo } \\
\hline & & $2008-2009$ & $2017-2018$ & 2008-2009 & $2017-2018$ \\
\hline \multirow{6}{*}{ Capital e RM urbano } & Norte & 2.604 & 3.079 & 1.392 .905 & 1.842 .813 \\
\hline & Nordeste & 5.475 & 6.465 & 4.598 .570 & 5.848 .439 \\
\hline & Sudeste & 3.790 & 5.922 & 11.255 .006 & 13.898 .820 \\
\hline & Sul & 1.230 & 1.771 & 2.355 .931 & 3.095 .900 \\
\hline & Centro-Oeste & 2.300 & 2.487 & 1.567 .120 & 2.367 .220 \\
\hline & Total & 15.399 & 19.724 & 21.169 .531 & 27.053.192 \\
\hline \multirow{6}{*}{ Interior urbano } & Norte & 2.726 & 2.710 & 1.510 .876 & 2.012 .621 \\
\hline & Nordeste & 9.353 & 9.050 & 6.542 .738 & 7.433 .228 \\
\hline & Sudeste & 7.650 & 6.433 & 12.054 .729 & 14.182 .905 \\
\hline & Sul & 3.918 & 4.431 & 5.168 .660 & 6.163 .633 \\
\hline & Centro-Oeste & 3.902 & 2.378 & 2.252 .510 & 2.454 .021 \\
\hline & Total & 27.549 & 25.002 & 27.529 .513 & 32.246 .408 \\
\hline \multirow{6}{*}{ Rural } & Norte & 2.281 & 2.476 & 1.029 .859 & 1.120 .670 \\
\hline & Nordeste & 4.404 & 3.605 & 3.934 .514 & 4.539 .400 \\
\hline & Sudeste & 2.638 & 2.550 & 2.123 .218 & 1.928 .628 \\
\hline & Sul & 1.568 & 2.145 & 1.350 .374 & 1.360 .305 \\
\hline & Centro-Oeste & 2.131 & 2.297 & 554.772 & 512.815 \\
\hline & Total & 13.022 & 13.073 & 8.992 .737 & 9.461 .818 \\
\hline \multirow{6}{*}{ Total } & Norte & 7.611 & 8.265 & 3.933 .640 & 4.976 .104 \\
\hline & Nordeste & 19.232 & 19.120 & 15.075 .822 & 17.821 .067 \\
\hline & Sudeste & 14.078 & 14.905 & 25.432 .953 & 30.010 .353 \\
\hline & Sul & 6.716 & 8.347 & 8.874 .965 & 10.619 .838 \\
\hline & Centro-Oeste & 8.333 & 7.162 & 4.374 .402 & 5.334 .056 \\
\hline & Total & 55.970 & 57.799 & 57.691 .781 & 68.761 .418 \\
\hline
\end{tabular}

Fonte: IBGE, microdados da POF 2008-2009 2017-2018

Elaboração do autor.

\subsection{Delimitação das despesas com tributos diretos}

Este estudo analisa a despesa domiciliar de quatro tributos diretos: IPTU, IPVA, IRPF sobre rendimentos do trabalho e contribuição previdenciária.

A despesa com IPTU das famílias brasileiras nas POFs inclui somente o pagamento do IPTU de imóveis residenciais e terrenos pertencentes às pessoas físicas. Segundo Carvalho Junior (2018b), o IPTU residencial representa em média entre 40\% e 60\% da arrecadação do IPTU em cidades com população acima de 100 mil habitantes, 
portanto espera-se que o total da despesa domiciliar com IPTU na POF esteja entre esse intervalo. No caso do IPVA, a POF contabiliza apenas o gasto com carros e motos de uso particular, não abrangendo a arrecadação tributária de veículos de pessoas jurídicas. Infelizmente, ainda não há uma estimativa do percentual da arrecadação do IPVA sobre veículos particulares na arrecadação global do imposto nos estados. De acordo com a POF, a última despesa mensal com IPTU está cadastrada na caderneta de despesa coletiva, que também mostra o número de meses que a despesa foi efetuada, já que o IPTU pode ser pago em parcela única (geralmente com desconto concedido pelas prefeituras) ou por parcelamento mensal. Na POF 2017/2018, a despesa com IPTU do domicílio principal está no quadro no 10 na caderneta de despesa coletiva, sob códigos 601, 602, 1101 e $1102 .{ }^{19}$ Para despesa com IPTU de outros imóveis está no quadro $\mathrm{n}^{\mathrm{o}} 47$, na caderneta de despesa individual, sob código $601 .^{20}$

A última despesa do mês com IPVA, na POF 2017-2018, está contida no quadro $\mathrm{n}^{\mathrm{o}} 50$ da caderneta de despesa individual com códigos de 101, 102, 103 e 1701. ${ }^{21} \mathrm{O}$ número de meses que houve a despesa (no caso do parcelamento do IPVA) também é mostrado pela caderneta. Membros de um mesmo domicilio podem ter mais de um automóvel e nesse caso o somatório da despesa com IPVA foi agregado por domicílio. A POF não distingue quando o imposto foi incidente sobre motocicletas (mais frequente entre os domicílios de baixa renda) ou sobre automóveis.

A análise da despesa com IRPF sobre rendimentos dos trabalhos será realizada através de quatro registros na POF 2017-2018. Primeiro, sendo o caso mais frequente, a dedução do IRPF na fonte do rendimento do trabalho, que está inserida no quadro no 53 na caderneta rendimento do trabalho na POF. Segundo, no quadro no 48 na caderneta de "despesa individual" como uma despesa com IRPF do ano corrente (Documento de Arrecadação de Receitas Federais - DARF do carnê-leão, código 3101) ou como complementação a pagar do IRPF referente ao ano anterior (DARF a pagar na Declaração do Imposto sobre a Renda da Pessoa Física - DIRPF, código 3102), ${ }^{22}$ representando apenas $2 \%$ dos casos. Terceiro, no quadro no 55, na caderneta "outros

19. Para a POF 2008-2009, os códigos do IPTU são o 501, 502, 1001, 1002 e 1003.

20. Para a POF 2008-2009, o código do IPTU para outros imóveis é 0801.

21. Para a POF 2008-2009, os códigos do IPVA são o 401, 402 e 403 e a despesa é mostrada de forma anualizada.

22. Para a POF 2008-2009, esses códigos da despesa individual com IRPF são o 3801 e 3802. 
rendimentos", com código $1901,{ }^{23}$ como sendo um rendimento da restituição ou devolução do imposto de renda do ano anterior (no caso a restituição diminui o IRPF descontado na fonte). ${ }^{24}$ Quarto, o IRPF ainda pode estar inserido dentro de "deduçóes" em outros tipos de rendimentos nos quadros nos 54 e 55 (benefícios previdenciários, décimo terceiro salário, participação nos lucros do empregado - PLR, aluguéis, venda de bens, aplicações financeiras etc.). No entanto, este estudo apenas estimará o IRPF incidente sobre os três primeiros rendimentos citados - benefícios previdenciários, décimo terceiro salário e PLR, aplicando a tabela padrão do IRPF sobre benefícios previdenciários de pessoas até 60 anos, e a tabela diferenciada sobre aposentados e pensionistas maiores de 60 anos e da PLR. Isso porque os rendimentos de capital possuem dedução significativa com taxa de administração e as regras do IRPF são muito complexas, havendo baixa probabilidade em se fazer uma estimação precisa. Com isso, este estudo imputou valores do IRPF na fonte para os rendimentos selecionados, mas limitando o valor dessa imputação ao valor total da própria dedução declarada. ${ }^{25}$

A despesa com contribuição previdenciária está inserida em três registros da POF 2017-2018. Primeiro, como uma dedução na fonte do rendimento do trabalho no quadro $\mathrm{n}^{\circ}$ 53, representado o maior número de casos. Segundo, no quadro no 48 na caderneta de despesa individual com Instituto Nacional do Seguro Social (INSS) (nos casos de contribuintes individuais e facultativos) com código de $501,{ }^{26}$ representando $14 \%$ dos domicílios que declararam despesa com contribuição previdenciária. Terceiro, dentro de deduçóes gerais do décimo terceiro salário dos trabalhadores e dos benefícios previdenciários do setor público que ultrapassaram o teto previdenciário do RGPS. O procedimento de estimação da contribuição previdenciária será feito

23. Para a POF 2008-2009, esses códigos de rendimento com restituição do IRPF são o 50401 e 50402.

24. Este estudo irá considerar o rendimento da restituição do IRPF do ano anterior como sendo um valor histórico médio anual e com isso irá imputar pagamento efetivo igual a zero de IRPF nos casos em que a restituição do ano anterior for igual ou superior ao valor recolhido na fonte do ano vigente.

25. Para aposentadorias e pensões de contribuintes acima de 65 anos em 2008 e 60 anos em 2018 foi aplicada a tabela do IRPF diferenciada para a categoria (com limite de isenção e faixas dobradas) e para a PLR também foi aplicada a tabela diferenciada para 2018. Além disso, a despesa estimada com contribuição previdenciária sobre o décimo terceiro salário dos trabalhadores, e das aposentadorias e pensões do setor público foi usada para abater a base de cálculo do IRPF. No caso do décimo terceiro salário aplicou-se a tabela progressiva do RGPS com alíquotas entre $8 \%$ e $11 \%$ e para aposentadorias e pensões do setor público, aplicou-se $11 \%$ sobre o que excedeu o teto do RGPS, calculado somente se 0 valor da dedução for maior que o IRPF estimado e sempre limitado ao saldo da dedução. É importante enfatizar que alguns sistemas de previdência subnacionais e dos militares não recolhem contribuição previdenciária sobre aposentadorias e pensões ou tem alíquotas diferentes.

26. Para a POF 2008-2009, os códigos da despesa individual com contribuições previdenciárias vão de 1801 até 1810. 
da seguinte maneira: após a estimação do IRPF como descrita no parágrafo anterior, caso ainda exista algum valor residual da dedução, e este rendimento seja o décimo terceiro salário ou um benefício previdenciário do setor público de valor superior ao teto previdenciário do INSS da época, então será estimado um valor de contribuição previdenciária equivalente a $11 \%$ sobre o exceder o teto do INSS e essa estimação de contribuição previdenciária ainda será utilizada para abater a base de cálculo do IRPF.

\subsection{Comparação entre as despesas com tributos diretos na POF e suas arrecadações efetivas}

Esta subseção compara os dados da despesa domiciliar com IPTU, IPVA, IRPF sobre os rendimentos do trabalho e a contribuição previdenciária com as suas respectivas arrecadaçóes efetivas divulgadas pela Secretaria do Tesouro Nacional e Secretaria da Receita Federal.

Neste estudo as despesas com IRPF sobre rendimentos do trabalho nas POFs abrangem: i) o desconto na fonte do IRPF sobre salários; ii) uma estimação do IRPF sobre aposentadorias, pensóes, décimo terceiro salário e PLR; iii) os pagamentos para o carnê-leão; e iv) o pagamento e a restituição da Declaração de Ajuste Anual do IRPF. As contribuiçôes previdenciárias incluem tanto aquelas destinadas ao RPPS da União, estados e municípios, quanto aquelas destinadas ao regime geral, RGPS. Na POF, as despesas com contribuiçóes previdenciárias para o RGPS somente abrangem: i) as contribuiçóes individuais de autônomos; ii) contribuiçóos de contribuintes de facultativos; e iii) o desconto na fonte do salário dos empregados e servidores públicos.

Conforme mencionado na seção anterior, na POF, o valor dedução na fonte dos rendimentos de aposentadorias, pensóes, décimo terceiro salário e PLR não é desagregado em "IRPF", "Previdência oficial", "ISS" e "outros" como ocorre com os salários, mas o estudo realizou uma estimativa do valor da dedução para o IRPF e contribuição previdenciária. A tabela 4 mostra os indicadores administrativos da arrecadação dos quatro tributos estudados entre 2008 e 2018, de forma a comparar com os valores levantados pela POF 2008-2009 e 2017-2018. 
TABELA 4

POF 2008-2009 e 2017-2018: comparação entre a arrecadação efetiva dos tributos diretos e suas respectivas despesas totais

(Em R\$ bilhões de dez./2019 e como \% do produto interno bruto - PIB)

\begin{tabular}{|c|c|c|c|c|c|c|c|c|}
\hline \multirow{2}{*}{ Ano } & \multicolumn{2}{|c|}{ IPTU (A) } & \multicolumn{2}{|c|}{ IPVA (B) } & \multicolumn{2}{|c|}{ IRPF sobre o trabalho } & \multicolumn{2}{|c|}{$\begin{array}{c}\text { Contribuição previdenciária } \\
\text { RGPS e RPPS' }\end{array}$} \\
\hline & $R \$$ & $\%$ PIB & $R \$$ & $\% \mathrm{PIB}$ & $R \$$ & $\% \mathrm{PIB}$ & $R \$$ & $\% \mathrm{PIB}$ \\
\hline \multicolumn{9}{|c|}{ Dados administrativos } \\
\hline 2008 & 23,38 & 0,41 & 30,58 & 0,53 & n. d. & n. d. & 97,86 & 1,71 \\
\hline 2009 & 24,93 & 0,42 & 35,39 & 0,60 & 92,00 & 1,57 & 163,57 & 2,78 \\
\hline 2010 & 27,12 & 0,42 & 35,43 & 0,55 & 99,58 & 1,54 & 212,33 & 3,89 \\
\hline 2011 & 28,71 & 0,42 & 37,37 & 0,55 & 107,59 & 1,57 & 143,03 & 2,58 \\
\hline 2012 & 29,89 & 0,42 & 39,42 & 0,56 & 110,93 & 1,56 & 147,72 & 2,48 \\
\hline 2013 & 31,63 & 0,43 & 40,17 & 0,54 & 109,91 & 1,48 & 155,80 & 2,46 \\
\hline 2014 & 31,92 & 0,43 & 40,98 & 0,55 & 114,04 & 1,53 & 156,64 & 2,38 \\
\hline 2015 & 33,14 & 0,47 & 41,34 & 0,59 & 110,38 & 1,57 & 150,14 & 2,32 \\
\hline 2016 & 35,33 & 0,51 & 42,00 & 0,60 & 111,11 & 1,59 & n. d. & n. d. \\
\hline 2017 & 38,15 & 0,54 & 42,28 & 0,60 & 120,34 & 1,69 & n. d. & n. d. \\
\hline 2018 & 47,14 & 0,66 & 46,70 & 0,65 & 123,52 & 1,73 & 147,80 & 2,11 \\
\hline \multicolumn{9}{|c|}{ Dados amostrais da $\mathrm{POF}^{2}$} \\
\hline $2008 / 2009$ & 14,75 & 0,25 & 25,39 & 0,43 & 84,15 & 1,45 & 106,01 & 1,83 \\
\hline $2017 / 2018$ & 23,64 & 0,35 & 29,71 & 0,43 & 124,82 & 1,82 & 148,50 & 2,09 \\
\hline
\end{tabular}

Fonte: IBGE (microdados da POF); Tesouro Nacional; Secretaria da Receita Federal.

Notas: ${ }^{~}$ Somente contribuição previdenciária de pessoas físicas.

Obs.: n. d. - não disponível.

De acordo com a tabela 4, a despesa com pagamento de IPTU pelas famílias brasileiras nas POFs 2008-2009 e 2017-2018 representaram 59\% e 53\% da arrecadação nacional do tributo em 2009 e 2018, respectivamente. Esses percentuais estáo dentro do esperado, visto que a arrecadação do IPTU não residencial (sobre empresas) tem representado cerca de $40 \%$ da arrecadaçáo total do imposto nas grandes cidades (Carvalho Junior, 2018b). A despesa domiciliar com IPVA nas POFs 2008-2009 e 2017-2018 representaram 72\% e 66\% das arrecadaçóes efetivas do imposto em 2009 e 2018 , respectivamente. ${ }^{27}$

27. Destaca-se que poucos casos apresentam valores elevadíssimos (outliers) para despesa declarada com IPTU e IPVA (mas que impactam enormemente a média do indicador). Com isso, este trabalho excluiu os outliers extremos para IPTU e IPVA, definidos como uma despesa superior a $5 \%$ da renda domiciliar para o caso do IPTU (1,5\% dos domićílios) e 7\% para o caso do IPVA (2,2\% dos domićlios). A técnica de exclusão de outliers extremos usada foi a Outlier Fence, que exclui valores iguais ou superiores a três vezes o intervalo interquartil no que estiver acima do terceiro quartil. 
Os dados das POFs 2008-2009 e 2017-2018 com as deduçóes sobre os rendimentos do trabalho, aposentarias, pensóes e o décimo terceiro salário relativas ao IRPF, bem como a despesa domiciliar com o carnê-leão e a despesa líquida com a Declaração de Ajuste Anual do IRPF, representaram 91\% e 101\% da arrecadação efetiva do IRPF sobre rendimentos do trabalho em 2009 e 2018, respectivamente. Isso mostra uma boa previsão para POF e da metodologia aplicada neste estudo.

Já a previsão das POFs 2008-2009 e 2017-2018 com as deduçôes sobre os salários relativas à contribuição previdenciária oficial (RGPS e RPPS), e aposentadorias e pensôes do setor público sujeitos a contribuição previdenciária do RPPS, bem como a despesa familiar com contribuiçâo individual ou facultativa ao RGPS foi menor que a arrecadação efetiva para 2009 para esteve em nível muito similar ao arrecadado em 2018. De fato, as previsóes das POFs 2008-2009 e 2017-2018 representaram 65\% e 100\% da arrecadação efetiva das contribuiçôes em 2009 e 2018, respectivamente. Essa diferença na validação dos dados previdenciários entre as duas POFs precisaria ser mais bem investigada entanto, podendo demonstrar um aumento da precisão dos dados da última POF.

\section{FREQUÊNCIA DOS TRIBUTOS DIRETOS}

Esta seçáo mostra a frequência de domicílios que declararam despesas com os tributos diretos nas POFs 2008-2009 e 2017-2018, por faixa de renda (tabela 5), e por estrato geográfico (tabela 6). Além disso, a seção também mostra a proporção de domicílios cobertos pela seguridade social no Brasil, ou seja, os domicílios que pagam contribuição previdenciária e aqueles que têm rendimentos em benefícios previdenciários ou programas assistenciais (tabela 7). 
Texto para

Discussão

TABELA 5

POF 2008-2009 e 2017-2018: frequência de domicílios com despesa em tributos diretos por percentil de renda domiciliar total

(Em \%)

\begin{tabular}{|c|c|c|c|c|c|c|c|c|}
\hline \multirow{2}{*}{$\begin{array}{l}\text { Faixa de percentil } \\
\text { de renda }\end{array}$} & \multicolumn{2}{|c|}{ IPTU } & \multicolumn{2}{|c|}{ IPVA } & \multicolumn{2}{|c|}{ IRPF sobre trabalho } & \multicolumn{2}{|c|}{ Previdência oficial } \\
\hline & 2008-2009 & $2017-2018$ & 2008-2009 & 2017-2018 & $2008-2009$ & $2017-2018$ & 2008-2009 & 2017-2018 \\
\hline 5,8 & 7,1 & 10,7 & 2,7 & 8,6 & 0,1 & 0,3 & 11,2 & 11,3 \\
\hline 24,1 & 13,0 & 19,5 & 5,6 & 13,3 & 0,5 & 0,4 & 30,7 & 31,2 \\
\hline 3,1 & 23,0 & 30,4 & 12,1 & 22,9 & 0,8 & 2,1 & 48,3 & 47,6 \\
\hline 66,6 & 33,6 & 41,7 & 24,6 & 37,6 & 4,5 & 13,9 & 64,1 & 66,6 \\
\hline 90,9 & 49,4 & 56,2 & 52,3 & 58,7 & 32,1 & 50,0 & 75,8 & 79,8 \\
\hline 95,4 & 61,2 & 74,1 & 74,9 & 73,4 & 70,9 & 77,9 & 81,0 & 84,6 \\
\hline 98,8 & 75,8 & 80,9 & 82,1 & 78,3 & 78,4 & 82,3 & 81,5 & 87,3 \\
\hline 100,0 & 73,2 & 92,0 & 82,1 & 81,0 & 79,4 & 79,3 & 85,5 & 84,5 \\
\hline 43,1 & 16,3 & 23,1 & 7,9 & 16,9 & 0,5 & 1,1 & 35,3 & 35,8 \\
\hline 90,9 & 41,6 & 49,1 & 38,6 & 48,3 & 18,5 & 32,3 & 70,1 & 73,3 \\
\hline 100,0 & 68,3 & 79,0 & 78,6 & 76,2 & 74,8 & 78,8 & 81,8 & 85,6 \\
\hline $0-100$ & 33,0 & 40,6 & 28,9 & 37,3 & 15,8 & 23,2 & 56,0 & 58,3 \\
\hline
\end{tabular}

Fonte: IBGE, microdados da POF 2008-2009 e 2017-2018.

Elaboração do autor.

TABELA 6

POF 2008-2009 e 2017-2018: frequência de domicílios com despesa em tributos diretos por estrato geográfico

(Em \%)

\begin{tabular}{|c|c|c|c|c|c|c|c|c|c|}
\hline \multirow{2}{*}{ Estrato geográfic } & & \multicolumn{2}{|c|}{ IPTU } & \multicolumn{2}{|c|}{ IPVA } & \multicolumn{2}{|c|}{ IRPF sobre trabalho } & \multicolumn{2}{|c|}{ Previdência oficial } \\
\hline & & $2008-2009$ & $2017-2018$ & $2008-2009$ & $2017-2018$ & $2008-2009$ & $2017-2018$ & $2008-2009$ & $2017-2018$ \\
\hline \multirow{6}{*}{ Capital e RM } & Norte & 12,6 & 22,0 & 15,6 & 24,6 & 17,0 & 23,4 & 57,5 & 58,1 \\
\hline & Nordeste & 18,3 & 27,1 & 17,2 & 27,3 & 15,6 & 21,5 & 58,0 & 63,0 \\
\hline & Sudeste & 40,0 & 43,9 & 33,5 & 38,6 & 25,8 & 32,3 & 66,6 & 66,1 \\
\hline & Sul & 45,3 & 62,0 & 42,2 & 52,1 & 25,1 & 39,8 & 66,9 & 68,6 \\
\hline & Centro-Oeste & 44,2 & 60,2 & 39,4 & 51,8 & 28,4 & 37,2 & 62,9 & 71,2 \\
\hline & Total & 34,4 & 42,3 & 30,2 & 37,9 & 23,1 & 30,7 & 63,9 & 65,6 \\
\hline \multirow{6}{*}{ Interior urbano } & Norte & 14,9 & 17,3 & 16,2 & 24,1 & 9,1 & 13,9 & 46,9 & 48,1 \\
\hline & Nordeste & 16,7 & 22,6 & 12,9 & 22,2 & 6,5 & 10,2 & 43,5 & 45,1 \\
\hline & Sudeste & 53,4 & 61,9 & 38,3 & 45,7 & 18,4 & 26,2 & 64,4 & 64,1 \\
\hline & Sul & 54,1 & 63,2 & 44,8 & 51,4 & 17,4 & 28,7 & 64,2 & 67,9 \\
\hline & Centro-Oeste & 32,4 & 50,3 & 26,3 & 41,6 & 10,8 & 23,0 & 52,1 & 64,5 \\
\hline & Total & 41,0 & 49,4 & 31,3 & 39,7 & 14,2 & 22,0 & 57,4 & 59,5 \\
\hline
\end{tabular}




\begin{tabular}{|c|c|c|c|c|c|c|c|c|c|}
\hline \multirow{2}{*}{\multicolumn{2}{|c|}{ Estrato geográfico }} & \multicolumn{2}{|c|}{ IPTU } & \multicolumn{2}{|c|}{ IPVA } & \multicolumn{2}{|c|}{ IRPF sobre trabalho } & \multicolumn{2}{|c|}{ Previdência oficial } \\
\hline & & 2008-2009 & $2017-2018$ & 2008-2009 & 2017-2018 & 2008-2009 & 2017-2018 & 2008-2009 & 2017-2018 \\
\hline \multirow{6}{*}{ Rural } & Norte & 3,0 & 1,9 & 10,3 & 15,5 & 3,8 & 4,5 & 27,0 & 25,9 \\
\hline & Nordeste & 1,6 & 2,0 & 6,5 & 15,6 & 1,1 & 2,7 & 22,1 & 24,2 \\
\hline & Sudeste & 9,1 & 12,1 & 28,1 & 40,4 & 5,2 & 9,4 & 46,4 & 42,9 \\
\hline & Sul & 10,1 & 9,2 & 38,7 & 51,1 & 5,1 & 8,1 & 42,7 & 46,4 \\
\hline & Centro-Oeste & 9,7 & 14,1 & 28,0 & 45,8 & 6,2 & 14,0 & 43,7 & 53,4 \\
\hline & Total & 5,0 & 5,7 & 18,2 & 27,4 & 3,3 & 5,7 & 32,8 & 33,0 \\
\hline \multirow{6}{*}{ Total } & Norte & 11,0 & 15,6 & 14,4 & 22,4 & 10,5 & 15,3 & 45,5 & 46,8 \\
\hline & Nordeste & 13,2 & 18,8 & 12,6 & 22,2 & 7,8 & 12,0 & 42,3 & 45,6 \\
\hline & Sudeste & 43,8 & 50,4 & 35,3 & 42,1 & 20,5 & 28,0 & 63,9 & 63,7 \\
\hline & Sul & 45,1 & 55,9 & 43,2 & 51,6 & 17,6 & 29,3 & 61,7 & 65,4 \\
\hline & Centro-Oeste & 33,8 & 51,2 & 31,2 & 46,5 & 16,5 & 28,4 & 54,9 & 66,4 \\
\hline & Total & 33,0 & 40,6 & 28,9 & 37,3 & 15,8 & 23,2 & 56,0 & 58,3 \\
\hline
\end{tabular}

Fonte: IBGE, microdados da POF 2008-2009 e 2017-2018. Elaboração do autor.

\subsection{Frequência do IPTU}

As tabelas 5 e 6 mostram apenas o percentual domicílios que efetivamente pagaram IPTU em cada faixa de renda e estrato geográfico. É importante destacar quatro principais motivos para que os domicílios náo pagarem IPTU: i) eles podem estar localizados em área rural; ii) podem estar legalmente isentos pelas prefeituras; iii) podem não estar inseridos no cadastro imobiliário municipal; ou iv) podem ser inadimplentes.

De acordo com a tabela 5, o percentual de contribuintes do IPTU variou progressivamente por percentil de renda domiciliar. O número de domicílios contribuintes no Brasil aumentou de 33\% em 2008-2009 para 41\% em 2017-2018. Em 2017/2018, apenas 23\% dos 43,1\% domićlios mais pobres eram contribuintes do IPTU. Já entre os 9,1\% mais ricos, $79 \%$ eram contribuintes do imposto. Nos estratos intermediários, a proporção de contribuintes foi de 49\%. Observa-se que em todos os estratos de renda, o IPTU teve um percentual de contribuintes superior ao IRPF sobre rendimentos do trabalho. Por exemplo, entre os 1,2\% mais ricos, $92 \%$ eram contribuintes do IPTU e 79\% eram contribuintes do IRPF sobre rendimentos do trabalho.

Analisando-se os estratos geográficos, a frequência de contribuintes do IPTU na POF 2017-2018, é significativamente maior nas regiôes Sul, Sudeste e Centro-Oeste (51\%), do que nas regióes Norte e Nordeste (18\%). Este fato é corroborado pelos dados 
arrecadatórios do IPTU nessas duas regióes e também na amostra de 53 municípios do estudo de Carvalho Júnior (2018b), que mostra indicadores de inadimplência do IPTU significativamente maior nessas regiôes (podendo ser superior a 50\% em municípios interior do Norte e Nordeste), além de falta de infraestrutura administrativa. A proporção de contribuintes do IPTU em domicílios rurais (6\%) foi muito pequena, visto que o IPTU é um imposto urbano. Nas capitais e RMs do Norte, Nordeste e Centro-Oeste, a proporção de contribuintes do IPTU foi superior que no interior urbano dessas regióes, embora na região Sudeste, provavelmente devido à maior informalidade metropolitana, o indicador dos municípios do interior foi superior. Na regiāo Sul, por outro lado, não houve grande diferença entre municípios metropolitanos e do interior. De acordo com microdados da POF 2017-2018, 67\% dos domicílios do interior de São Paulo eram contribuintes do IPTU em oposição ao interior da região Norte, onde apenas 17\% eram contribuintes.

\subsection{Frequência do IPVA}

De acordo com a tabela 5, o percentual de contribuintes do IPVA aumentou progressivamente por percentil de renda domiciliar. Além disso, o número de domicílios contribuintes em todo o Brasil aumentou de 29\% em 2008/2009 para $37 \%$ em 2017-2018. Entre os 43,1\% mais pobres, o indicador aumentou de $8 \%$ para $17 \%$. Já entre os $9,1 \%$ mais ricos, esse percentual permaneceu ao redor $77 \%$ nas duas pesquisas, e nos demais estratos de renda intermediários, ele aumentou de $39 \%$ para 48\%. O aumento de contribuintes do IPVA entre os mais pobres ocorreu devido ao aumento da propriedade de veículos nesta classe. As tabelas 7 e 8 mostram a distribuição por percentil de renda e por estrato geográfico da propriedade de motocicletas e automóveis nas duas últimas POFs.

De acordo com a tabela 7, o percentual de domicílios brasileiros que possuíam algum meio de transporte motorizado individual, motocicleta ou automóvel, aumentou de 42\% para 58\% entre 2008-2009 e 2017-2018. Considerando-se apenas os 43,1\% domicílios mais pobres, 19\% tinham motocicleta ou automóvel em 2008-2009 (12\% motocicleta e 9\% automóvel). Em 2017-2018, esse percentual dobrou, aumentando para 38\% (22\% motocicleta e $21 \%$ automóvel). Evidentemente o percentual de domicílios contribuintes do IPVA foi menor que o percentual de domicílios que possuíam carro ou moto (principalmente nos estratos de renda mais baixos), visto que a legislação estadual pode isentar determinados veículos de baixo valor ou uma parte dos domicílios pode ser 
inadimplente com o imposto. Os dados da POF 2017-2018 mostram um número total de 31,61 milhóes de automóveis particulares declarados pelos domicílios, representando 59\% dos 53,16 milhôes de todos os automóveis (de pessoas físicas e jurídicas) registrados pelo Departamento Nacional de Trânsito (Denatran) em 2018. Além disso, os dados também mostraram 15,27 milhōes de motocicletas declaradas pelos domicílios, representando $70 \%$ de todas as 21,72 milhóes efetivamente registradas em 2018.

TABELA 7

POF 2008-2009 e 2017-2018: frequência de domicílios com propriedade de motocicletas e automóveis por percentil de renda domiciliar total (Em \%)

\begin{tabular}{|c|c|c|c|c|c|c|}
\hline \multirow{2}{*}{ Faixa de percentil de renda } & \multicolumn{2}{|c|}{ Motocicleta } & \multicolumn{2}{|c|}{ Automóvel } & \multicolumn{2}{|c|}{ Motocicleta ou automóvel } \\
\hline & $2008-2009$ & $2017-2018$ & $2008-2009$ & $2017-2018$ & $2008-2009$ & $2017-2018$ \\
\hline 5,8 & 7,8 & 21,7 & 3,8 & 10,5 & 11,1 & 29,7 \\
\hline 24,1 & 9,4 & 21,4 & 6,6 & 16,5 & 15,0 & 33,9 \\
\hline 43,1 & 11,5 & 21,7 & 15,4 & 28,5 & 25,0 & 43,8 \\
\hline 66,6 & 16,1 & 25,1 & 29,5 & 47,6 & 40,9 & 60,5 \\
\hline 90,9 & 18,2 & 23,1 & 59,9 & 72,4 & 67,2 & 78,1 \\
\hline 95,4 & 17,6 & 17,6 & 83,0 & 87,9 & 85,2 & 89,5 \\
\hline 98,8 & 12,0 & 13,4 & 86,4 & 90,5 & 87,9 & 91,6 \\
\hline 100,0 & 9,0 & 11,3 & 87,6 & 94,3 & 88,7 & 95,0 \\
\hline 43,1 & 10,0 & 21,6 & 9,8 & 21,0 & 18,6 & 37,7 \\
\hline 90,9 & 17,2 & 24,1 & 44,9 & 60,2 & 54,2 & 69,5 \\
\hline 100,0 & 14,4 & 15,2 & 84,9 & 89,7 & 86,6 & 91,0 \\
\hline $0-100,0$ & 33,0 & 40,6 & 28,9 & 37,3 & 41,6 & 57,7 \\
\hline
\end{tabular}

Fonte: IBGE, microdados da POF 2008-2009 e 2017-2018.

Elaboração do autor.

Já pelos dados geográficos da tabela 6, o percentual de pagantes do IPVA na POF 2017-2018 é significativamente maior nas regiôes Sul, Sudeste e Centro-Oeste (45\% dos domicílios), do que nas regiôes Norte e Nordeste (22\% dos domicílios). Este fato é corroborado pelos dados arrecadatórios per capita do IPVA por estados. A proporção de pagantes do IPVA em domicílios rurais (27\%) foi menor que em domicílios urbanos (38\%). Na regiáo Sudeste, a proporçáo de contribuintes no interior urbano foi maior que nas capitais e RMs, provavelmente porque além da diferença de renda não ser tão significativa, as características urbanas das metrópoles do Sudeste fazem com que os veículos particulares sejam menos demandados. Por outro lado, na regiáo Centro-Oeste, a proporção de contribuintes do IPVA foi maior nas capitais e 
RMs, provavelmente devido a maior renda e as características urbanas das capitais do Centro-Oeste que são menos densas. Os dados geográficos da tabela 8 também mostram um aumento significativo da propriedade de motocicleta ou automóvel em domicílios rurais, passando de 38\% para 61\% entre 2008-2009 e 2017-2018. O aumento também foi expressivo nas regiōes Norte e Nordeste, passando de $27 \%$ para $49 \%$. No entanto, em 2017-2018, comparando-se nesses dois estratos a frequência da propriedade de veículos com pagantes do IPVA, a diferença foi significativamente, sendo de $61 \%$ versus $28 \%$ e $49 \%$ versus $22 \%$, respectivamente.

TABELA 8

POF 2008-2009 e 2017-2018: frequência domiciliar da propriedade de motos e carros por estrato geográfico

(Em \%)

\begin{tabular}{|c|c|c|c|c|c|c|c|}
\hline \multirow{2}{*}{\multicolumn{2}{|c|}{ Estrato geográfico }} & \multicolumn{2}{|c|}{ Motocicleta } & \multicolumn{2}{|c|}{ Automóvel } & \multicolumn{2}{|c|}{ Motocicleta ou automóvel } \\
\hline & & 2008-2009 & 2017-2018 & 2008-2009 & $2017-2018$ & 2008-2009 & $2017-2018$ \\
\hline \multirow{6}{*}{ Capital e RM } & Norte & 8,5 & 18,7 & 18,9 & 30,1 & 24,9 & 43,0 \\
\hline & Nordeste & 6,4 & 15,3 & 22,0 & 35,1 & 26,7 & 44,9 \\
\hline & Sudeste & 5,3 & 8,1 & 38,4 & 48,7 & 40,9 & 51,8 \\
\hline & Sul & 9,5 & 10,8 & 46,6 & 63,5 & 51,0 & 66,3 \\
\hline & Centro-Oeste & 9,8 & 17,6 & 45,1 & 59,8 & 50,0 & 66,8 \\
\hline & Total & 6,6 & 11,5 & 34,9 & 42,7 & 38,6 & 52,7 \\
\hline \multirow{6}{*}{ Interior urbano } & Norte & 22,0 & 42,3 & 14,1 & 23,6 & 30,8 & 55,4 \\
\hline & Nordeste & 17,6 & 33,8 & 14,9 & 24,6 & 28,7 & 48,7 \\
\hline & Sudeste & 14,7 & 20,6 & 43,9 & 56,6 & 50,2 & 63,2 \\
\hline & Sul & 16,7 & 18,7 & 50,8 & 65,4 & 58,0 & 69,8 \\
\hline & Centro-Oeste & 24,0 & 34,1 & 30,1 & 51,0 & 46,0 & 67,2 \\
\hline & Total & 16,9 & 25,7 & 35,5 & 48,4 & 45,2 & 60,9 \\
\hline \multirow{6}{*}{ Rural } & Norte & 18,0 & 36,5 & 7,6 & 16,2 & 22,9 & 44,4 \\
\hline & Nordeste & 21,5 & 46,8 & 7,1 & 17,8 & 26,7 & 55,8 \\
\hline & Sudeste & 20,7 & 36,2 & 33,9 & 52,7 & 46,9 & 70,3 \\
\hline & Sul & 23,4 & 31,1 & 54,0 & 68,2 & 62,2 & 75,0 \\
\hline & Centro-Oeste & 24,5 & 42,7 & 34,6 & 60,0 & 51,4 & 77,6 \\
\hline & Total & 21,4 & 41,0 & 22,2 & 34,3 & 37,9 & 61,4 \\
\hline \multirow{6}{*}{ Total } & Norte & 16,1 & 32,3 & 14,1 & 24,4 & 26,7 & 48,3 \\
\hline & Nordeste & 15,2 & 31,0 & 15,0 & 26,3 & 27,6 & 49,3 \\
\hline & Sudeste & 11,0 & 15,8 & 40,6 & 52,7 & 45,8 & 58,4 \\
\hline & Sul & 15,8 & 18,0 & 50,2 & 65,2 & 56,8 & 69,4 \\
\hline & Centro-Oeste & 19,0 & 27,6 & 36,0 & 55,7 & 48,1 & 68,0 \\
\hline & Total & 13,8 & 22,2 & 33,2 & 46,0 & 41,6 & 57,7 \\
\hline
\end{tabular}

Fonte: IBGE, microdados da POF 2008-2009 e 2017-2018.

Elaboração do autor. 


\subsection{Frequência do IRPF}

De acordo com a tabela 5, a frequência de contribuintes do IRPF sobre rendimentos do trabalho aumentou progressivamente por estrato de renda domiciliar, pelo menos até o percentil 98,8 (renda até 36 SMs em 2018), permanecendo estável em $80 \%$ dos domicílios com tendência de um ligeiro decréscimo partir dos 1,2\% com maior renda. As principais causas para a estagnação da frequência de contribuintes do IRPF sobre rendimentos do trabalho entre os top $1 \%$ seriam: i) o teto do funcionalismo público era de $\mathrm{R} \$ 33.763$ até 2018 e portanto a classe do último estrato de renda domiciliar provavelmente tem maior peso de empresários e profissionais liberais pejotizados que estão legalmente isentos da tributação sobre lucros e dividendos; ii) prevalência de outros tipos de rendimentos que não o trabalho, como aluguéis, ganhos de capitais, investimentos financeiros etc.; e iii) maior facilidade em sonegação fiscal desta classe.

De qualquer maneira, o percentual de domicílios contribuintes do IRPF aumentou significativamente entre as últimas duas POFs, passando de 16\% em 2008-2009 para $23 \%$ em 2017-2018. ${ }^{28}$ No entanto, esse aumento de contribuintes do IRPF ocorreu basicamente nos estratos intermediários de renda, entre os percentis 43,1 e 90,9, aumentando de $19 \%$ para $32 \%$. Apenas $1 \%$ dos $43,1 \%$ domicílios mais pobres (renda até $3 \mathrm{SMs}$ ) eram contribuintes IRPF. Já entre os 9,1\% domicílios mais ricos (renda acima de 12 SMs), 79\% eram contribuintes do imposto em 2017-2018, percentual que não se alterou significativamente entre as duas POFs neste estrato.

Os dados geográficos da tabela 6 mostram que o percentual de pagantes do IRPF sobre rendimentos do trabalho na POF 2017-2018 é significativamente maior nas regiốes Sul, Sudeste e Centro-Oeste (28\% de domicílios contribuintes), do que nas regiôes Norte e Nordeste (13\% de domicílios contribuintes), devido a menor renda per capita dessas duas últimas regiôes. A proporção de pagantes do IRPF sobre rendimentos do trabalho em domicílios rurais (6\%) foi bastante inferior que em domicílios urbanos (26\%), evidenciando o baixo nível de rendimentos dos trabalhadores rurais. O percentual de contribuintes do IRPF em domicílios de capitais e RM (31\%) foi superior que em

28. Segundo a Receita Federal do Brasil, entre 2009 e 2018, o número de declarações com IRPF devido aumentou de 10,0 milhões para 19,4 milhões, representando 15,8\% e 27,3\% do número de domićlios nos respectivos anos. Uma das causas da ligeira maior frequência na base da Receita Federal do Brasil em 2018 é provavelmente a declaração de mais de uma pessoa por domicílio. 
domicílios do interior urbano (22\%). A maior proporção de domicílios contribuintes do IRPF é encontrada nas capitais e RM do Sul, Sudeste e Centro-Oeste, onde 34\% dos domicílios sáo contribuintes do imposto.

\subsection{Frequência da contribuição previdenciária}

De acordo com a tabela 5, o percentual de domicílios pagantes de contribuição previdenciária oficial se situou mais ou menos em um mesmo patamar entre as POFs 2008-2009 e 2017-2018, ao redor de 57\%, tendência seguida em todos os estratos de renda. A frequência de pagantes de contribuiçáo previdenciária aumentou progressivamente os $9,1 \%$ mais ricos, quando passou a se manter estável em cerca de $85 \%$ dos domicílios. Entre os 43,1\% domicílios mais pobres na POF 2017-2018, $36 \%$ pagavam contribuição previdenciária e nos demais estratos intermediários, esse percentual foi de $73 \%$.

Pela tabela 6, observa-se que na POF 2017-2018, cerca de 64\% dos domicílios urbanos pagavam contribuição previdenciária, mas apenas 33\% dos domicílios rurais. Essa diferença se justifica devido às regras diferenciadas da previdência rural. $\mathrm{O}$ maior percentual de domicílios pagantes (59\%) foi encontrado nas capitais e RMs das regióes Sul, Sudeste e Centro-Oeste, e o menor percentual foi encontrado no interior e na zona rural das regiôes Norte e Nordeste (39\% e 20\%, respectivamente).

\subsection{Frequência dos benefícios da seguridade social}

Conforme abordado na seção anterior, 58\% dos domicílios brasileiros pagaram algum tipo de contribuição previdenciária na POF 2017-2018. Observa-se que esse indicador de contribuintes não contempla todos os beneficiários do sistema, visto que a grande maioria de aposentadorias, pensóes, benefícios assistenciais da Lei Orgânica da Assistência Social (Loas), e outros programas assistenciais, não pagam contribuição previdenciária. Caso adicionássemos aos pagantes das contribuiçóes previdenciárias, os aposentados e pensionistas do RGPS e RPPS, beneficiários da Loas e os beneficiários do seguro-desemprego, a abrangência alcançaria $80 \%$ dos domicílios. Por fim, caso adicionássemos ainda os beneficiários de outros programas assistenciais, como o Bolsa Família e demais programas nacionais e subnacionais de transferência de renda, essa abrangência aumentaria para $88 \%$. As tabelas 9 e 10 mostram o percentual de domicílios com algum membro que seja atingido pela seguridade social, isto é, seja 
pagante de contribuição previdenciária, beneficiário da RGPS, RPPS ou Loas, do seguro-desemprego ou de programas assistenciais.

TABELA 9

POF 2017-2018: frequência de domicílios atingidos pela seguridade social, por percentil de renda domiciliar total

\begin{tabular}{lccccc}
\hline Faixa de percentil & Contribuintes previdência & Beneficiários previdência & Seguro-desemprego & Programas assistenciais & Total \\
\hline 5,8 & 11,3 & 5,3 & 0,8 & 50,2 & $\mathbf{6 2 , 4}$ \\
24,1 & 31,2 & 35,0 & 1,8 & 27,8 & $\mathbf{8 0 , 1}$ \\
43,1 & 47,6 & 43,5 & 2,4 & 16,9 & $\mathbf{8 7 , 8}$ \\
66,6 & 66,6 & 41,3 & 4,3 & 10,0 & $\mathbf{9 1 , 2}$ \\
90,9 & 79,8 & 41,1 & 4,8 & 3,9 & $\mathbf{9 4 , 1}$ \\
95,4 & 84,6 & 44,7 & 3,0 & 1,5 & $\mathbf{9 4 , 0}$ \\
98,8 & 87,3 & 43,8 & 1,5 & 0,7 & $\mathbf{9 4 , 9}$ \\
100,0 & 84,5 & 47,9 & 1,9 & 1,0 & $\mathbf{9 3 , 3}$ \\
\hline 43,1 & 35,8 & 34,8 & 1,9 & 26,0 & $\mathbf{8 1 , 1}$ \\
90,9 & 73,3 & 41,2 & 4,6 & 6,9 & $\mathbf{9 2 , 7}$ \\
100,0 & 85,6 & 44,7 & 2,3 & 1,1 & $\mathbf{9 4 , 2}$ \\
\hline $\mathbf{0 - 1 0 0 , 0}$ & $\mathbf{5 8 , 3}$ & $\mathbf{3 8 , 8}$ & $\mathbf{3 , 2}$ & $\mathbf{1 4 , 6}$ & $\mathbf{8 7 , 8}$ \\
\hline \multicolumn{1}{r}{ Fonte: IBGE, microdados da POF 2017-2018. } & & & &
\end{tabular}

De acordo com os dados da tabela 9, na POF 2017-2018, exceto no primeiro estrato (renda até $1 \mathrm{SM}$ ), o percentual de domicílios que possuía algum morador com rendimentos de aposentadoria ou pensão variou entre 35\% e 45\%. Por outro lado, metade dos domicílios do primeiro estrato são beneficiários de programas assistenciais. $\mathrm{O}$ percentual de domicílios com algum beneficiário de seguro-desemprego foi mais frequente nos estratos intermediários, ao redor de 5\%. No Brasil, 15\% dos domićlios foram beneficiários de programas assistenciais, de acordo com a POF 2017-2018. Eles atingiram sobretudo os menores estratos de renda, chegando a 50\% dos domicílios com renda domiciliar inferior a 1 SM e a $26 \%$ de todos os domicílios com renda domiciliar inferior a 3 SMs. A última coluna da tabela mostra que $88 \%$ dos domicílios brasileiros estão amparados com algum meio de proteçáo social citado: previdência social (trabalhadores contribuintes, aposentados e pensionistas, beneficiários da Loas, seguro-desemprego e programas assistenciais de renda básica como o Bolsa Família e demais programas dos entes subnacionais. 
TABELA 10

POF 2017-2018: frequência de domicílios atingidos pela seguridade social, por estrato geográfico

\begin{tabular}{|c|c|c|c|c|c|c|}
\hline \multicolumn{2}{|c|}{ Estrato geográfico } & \multirow{2}{*}{$\frac{\text { Contribuintes previdência }}{58,1}$} & \multirow{2}{*}{$\frac{\text { Beneficiários previdência }}{25,2}$} & \multirow{2}{*}{$\frac{\text { Seguro-desemprego }}{2,6}$} & \multirow{2}{*}{$\frac{\text { Programas assistenciais }}{19,0}$} & \multirow{2}{*}{$\begin{array}{l}\text { Total } \\
79,8\end{array}$} \\
\hline \multirow{6}{*}{ Capital e RM } & Norte & & & & & \\
\hline & Nordeste & 63,0 & 35,6 & 3,8 & 17,8 & 87,5 \\
\hline & Sudeste & 66,1 & 37,5 & 3,6 & 6,8 & 87,9 \\
\hline & Sul & 68,6 & 39,2 & 3,2 & 4,0 & 89,3 \\
\hline & Centro-Oeste & 71,2 & 34,9 & 4,6 & 5,8 & 87,8 \\
\hline & Total & 65,6 & 36,2 & 3,6 & 9,6 & 87,4 \\
\hline \multirow{6}{*}{ Interior urbano } & Norte & 48,1 & 27,8 & 2,3 & 23,3 & 79,1 \\
\hline & Nordeste & 45,1 & 40,0 & 2,8 & 30,2 & 88,9 \\
\hline & Sudeste & 64,1 & 43,1 & 3,3 & 7,1 & 90,1 \\
\hline & Sul & 67,9 & 40,5 & 3,9 & 4,9 & 89,2 \\
\hline & Centro-Oeste & 64,5 & 31,5 & 4,3 & 11,5 & 87,6 \\
\hline & Total & 59,5 & 40,0 & 3,3 & 13,4 & 88,8 \\
\hline \multirow{6}{*}{ Rural } & Norte & 25,9 & 29,2 & 1,0 & 41,6 & 78,3 \\
\hline & Nordeste & 24,2 & 44,2 & 1,6 & 47,0 & 91,0 \\
\hline & Sudeste & 42,9 & 40,3 & 2,7 & 16,9 & 82,2 \\
\hline & Sul & 46,4 & 49,4 & 1,7 & 8,8 & 82,6 \\
\hline & Centro-Oeste & 53,4 & 30,2 & 2,6 & 16,2 & 81,5 \\
\hline & Total & 33,0 & 41,6 & 1,8 & 33,1 & 86,0 \\
\hline \multirow{6}{*}{ Total } & Norte & 46,8 & 27,2 & 2,2 & 25,8 & 79,2 \\
\hline & Nordeste & 45,6 & 39,6 & 2,8 & 30,4 & 89,0 \\
\hline & Sudeste & 63,7 & 40,3 & 3,4 & 7,6 & 88,5 \\
\hline & Sul & 65,4 & 41,3 & 3,4 & 5,2 & 88,4 \\
\hline & Centro-Oeste & 66,4 & 32,9 & 4,3 & 9,4 & 87,1 \\
\hline & Total & 58,3 & 38,8 & 3,2 & 14,6 & 87,8 \\
\hline
\end{tabular}

Fonte: IBGE, microdados da POF 2017-2018.

Elaboração do autor.

Os dados da tabela 10 não apresentam muitas variaçôes regionais com relação a proporção de domicílios com moradores que tenham benefícios previdenciários, entre $35 \%$ e $45 \%$ em quase todos os estratos geográficos. A exceção se encontra na região Norte (27\%). A proporção de domicílios com beneficiários de seguro-desemprego foi mais alta nas zonas urbanas (média de 3,5\%) do que nas zonas rurais (média de 1,8\%). Com relação a frequência dos programas assistenciais, ela foi muito maior no Norte e Nordeste, tanto na zona rural (46\%), quanto nos municípios do interior (29\%), e nas capitais e RMs (18\%). Cerca de um terço dos domicílios rurais no Brasil eram contemplados com algum programa assistencial, sendo apenas 6\% no Centro-Sul urbano. 
Os microdados da POF mostram ainda uma elevada iniquidade em relação aos valores médios dos benefícios de proteção social. Os benefícios previdenciários do RGPS e RPPS tiveram, respectivamente, valor médio de $\mathrm{R} \$ 1.383$ e $\mathrm{R} \$ 4.380$, o seguro-desemprego de $\mathrm{R} \$ 3.511$, e os benefícios assistenciais de apenas $\mathrm{R} \$ 326$.

\section{PARTICIPAÇÃO DOS TRIBUTOS DIRETOS NA RENDA DOMICILIAR}

Esta seção mostra a participação da despesa anual com tributos diretos na renda domiciliar anual, bem como sua distribuição por estratos de renda e por estrato geográfico. A seção analisa três indicadores. $\mathrm{O}$ primeiro indica a participação dos tributos diretos por estrato de renda domiciliar em todos os domicílios brasileiros (independentemente de serem pagantes ou náo de cada um dos tributos, tabela 11). O segundo indica a participação dos tributos diretos por estrato de renda domiciliar apenas entre os domicílios pagantes do imposto. Este último indicador contido na tabela 12 se justifica para avaliar o padrão de progressividade/regressividade da legislação e da administração do tributo, ${ }^{29}$ ou seja, se o desenho da legislação tributária expresso entre os contribuintes do imposto e/ou a forma como ele é administrado é na prática progressivo ou não (os casos de contribuintes inadimplentes, sonegadores e não cadastrados pelo fisco não impacta o indicador, podendo ser uma melhor aproximação do nível de progressividade da estrutura tributária, embora ele também desconsidere os legalmente isentos, o que já faz parte da estrutura do imposto). Por fim, o terceiro mostra a participação dos tributos diretos na renda domiciliar em todos os domicílios por estrato geográfico (tabela 13). Além disso, gráfico 1 sintetiza os dados da tabela 11, mostrando a composição e distribuição da carga tributária dos tributos diretos por percentil de renda em todos os domicílios na POF 2017-2018.

29. Um exemplo de regressividade da administração tributária seria o IPTU, onde pode ocorrer a avaliação de imóveis de alto valor de mercado com uma defasagem maior que imóveis de baixo valor. Já um exemplo de regressividade causada pela legislação seria o IRPF, onde a exclusão de despesas médicas da base de cálculo impacta mais fortemente a alíquota efetiva dos mais ricos. 
TABELA 11

POF 2008-2009 e 2017-2018: razão entre despesa com tributos diretos e renda domiciliar total por percentil de renda domiciliar, universo de todos os domicílios, média das razões

(Em \%)

\begin{tabular}{|c|c|c|c|c|c|c|c|c|c|c|}
\hline \multirow{2}{*}{$\begin{array}{l}\text { Faixa de } \\
\text { percentil }\end{array}$} & \multicolumn{2}{|c|}{ IPTU $^{1}$} & \multicolumn{2}{|c|}{ IPVA' $^{1}$} & \multicolumn{2}{|c|}{ IRPF sobre trabalho } & \multicolumn{2}{|c|}{ Previdência } & \multicolumn{2}{|c|}{ Total } \\
\hline & $2008-2009$ & $2017-2018$ & $2008-2009$ & $2017-2018$ & $2008-2009$ & $2017-2018$ & 2008-2009 & 2017-2018 & $2008-200$ & 2017-2018 \\
\hline 5,8 & 0,05 & 0,13 & 0,05 & 0,20 & 0,00 & 0,01 & 0,45 & 0,69 & 0,55 & 1,03 \\
\hline 24,1 & 0,15 & 0,20 & 0,14 & 0,29 & 0,01 & 0,01 & 1,26 & 1,44 & 1,56 & 1,94 \\
\hline 43,1 & 0,26 & 0,33 & 0,24 & 0,41 & 0,01 & 0,03 & 1,87 & 2,07 & 2,38 & 2,84 \\
\hline 66,6 & 0,37 & 0,38 & 0,39 & 0,59 & 0,10 & 0,24 & 2,52 & 2,86 & 3,38 & 4,07 \\
\hline 90,9 & 0,47 & 0,46 & 0,63 & 0,74 & 0,80 & 1,58 & 3,27 & 3,60 & 5,17 & 6,38 \\
\hline 95,4 & 0,55 & 0,55 & 0,75 & 0,77 & 3,09 & 4,50 & 3,63 & 3,74 & 8,02 & 9,56 \\
\hline 98,8 & 0,58 & 0,57 & 0,68 & 0,67 & 5,73 & 6,72 & 3,64 & 3,87 & 10,63 & 11,83 \\
\hline 100,0 & 0,65 & 0,59 & 0,61 & 0,55 & 6,52 & 7,21 & 3,55 & 2,87 & 11,33 & 11,22 \\
\hline 43,1 & 0,18 & 0,25 & 0,17 & 0,33 & 0,01 & 0,02 & 1,40 & 1,62 & 1,76 & 2,22 \\
\hline 90,9 & 0,42 & 0,42 & 0,51 & 0,67 & 0,48 & 0,92 & 2,90 & 3,24 & 4,31 & 5,25 \\
\hline 100,0 & 0,57 & 0,56 & 0,71 & 0,71 & 4,56 & 5,69 & 3,62 & 3,67 & 9,46 & 10,63 \\
\hline $0-100,0$ & 0,33 & 0,36 & 0,38 & 0,53 & 0,65 & 0,96 & 2,31 & 2,58 & 3,67 & 4,43 \\
\hline
\end{tabular}

Fonte: IBGE, microdados da POF 2008-2009 e 2017-2018.

Elaboração do autor.

Nota: 1 Excluindo-se os outliers.

TABELA 12

POF 2008-2009 e 2017-2018: razão entre despesa com tributos diretos e renda domiciliar por percentil de renda domiciliar, apenas domicílios pagantes

\begin{tabular}{|c|c|c|c|c|c|c|c|c|}
\hline \multirow{2}{*}{ Faixa de percentil } & \multicolumn{2}{|c|}{ IPTU' } & \multicolumn{2}{|c|}{ IPVA' $^{1}$} & \multicolumn{2}{|c|}{ IRPF } & \multicolumn{2}{|c|}{ Previdência } \\
\hline & 2008-2009 & $2017-2018$ & 2008-2009 & 2017-2018 & 2008-2009 & 2017-2018 & 2008-2009 & 2017-2018 \\
\hline 5,8 & 1,85 & 1,62 & 3,59 & 3,46 & - & - & 4,01 & 6,10 \\
\hline 24,1 & 1,56 & 1,18 & 2,69 & 2,52 & - & - & 4,10 & 4,62 \\
\hline 43,1 & 1,36 & 1,12 & 2,06 & 1,93 & - & - & 3,87 & 4,35 \\
\hline 66,6 & 1,21 & 0,93 & 1,59 & 1,63 & 2,35 & 1,71 & 3,93 & 4,29 \\
\hline 90,9 & 1,00 & 0,82 & 1,21 & 1,28 & 2,65 & 3,15 & 4,31 & 4,51 \\
\hline 95,4 & 0,91 & 0,74 & 1,01 & 1,06 & 4,41 & 5,78 & 4,48 & 4,42 \\
\hline 98,8 & 0,79 & 0,70 & 0,83 & 0,86 & 7,34 & 8,17 & 4,46 & 4,43 \\
\hline 100,0 & 0,91 & 0,65 & 0,75 & 0,68 & 8,23 & 9,09 & 4,16 & 3,39 \\
\hline 43,1 & 1,44 & 1,17 & 2,30 & 2,20 & - & - & 3,97 & 4,53 \\
\hline 90,9 & 1,08 & 0,87 & 1,33 & 1,42 & 2,61 & 2,85 & 4,14 & 4,41 \\
\hline 100,0 & 0,86 & 0,71 & 0,90 & 0,93 & 6,10 & 7,13 & 4,43 & 4,29 \\
\hline $0-100,0$ & 1,10 & 0,91 & 1,33 & 1,46 & 4,10 & 4,15 & 4,13 & 4,43 \\
\hline
\end{tabular}

Fonte: IBGE, microdados da POF 2008-2009 e 2017-2018.

Elaboração do autor.

Nota: ${ }^{1}$ Excluindo-se os outliers. 
TABELA 13

POF 2008-2009 e 2017-2018: razão entre despesa com tributos diretos e renda domiciliar por estrato geográfico, universo de todos os domicílios, média das razões

(Em \%)

\begin{tabular}{|c|c|c|c|c|c|c|c|c|c|c|c|}
\hline \multirow{2}{*}{\multicolumn{2}{|c|}{ Estrato geográfico }} & \multicolumn{2}{|c|}{ IPTU $^{1}$} & \multicolumn{2}{|c|}{ IPVA' $^{\prime}$} & \multicolumn{2}{|c|}{ IRPF } & \multicolumn{2}{|c|}{ Previdência } & \multicolumn{2}{|c|}{ Total } \\
\hline & & 2008-2009 & 2017-2018 & $2008-2009$ & $2017-2018$ & $2008-2009$ & $2017-2018$ & $2008-2009$ & 2017-2018 & $2008-20$ & 017-2018 \\
\hline \multirow{6}{*}{$\begin{array}{l}\text { Capital } \\
\text { e RM }\end{array}$} & Norte & 0,10 & 0,22 & 0,18 & 0,34 & 0,67 & 1,00 & 2,29 & 2,59 & 3,24 & 4,15 \\
\hline & Nordeste & 0,19 & 0,21 & 0,18 & 0,34 & 0,75 & 0,94 & 2,45 & 2,76 & 3,57 & 4,25 \\
\hline & Sudeste & 0,45 & 0,50 & 0,46 & 0,54 & 1,19 & 1,44 & 2,83 & 2,94 & 4,93 & 5,42 \\
\hline & Sul & 0,47 & 0,62 & 0,48 & 0,67 & 1,04 & 1,78 & 2,86 & 3,02 & 4,85 & 6,09 \\
\hline & Centro-Oeste & 0,54 & 0,50 & 0,51 & 0,68 & 1,78 & 2,23 & 2,85 & 3,32 & 5,68 & 6,73 \\
\hline & Total & 0,37 & 0,43 & 0,39 & 0,51 & 1,09 & 1,41 & 2,72 & 2,92 & 4,57 & 5,27 \\
\hline \multirow{6}{*}{$\begin{array}{l}\text { Interior } \\
\text { urbano }\end{array}$} & Norte & 0,13 & 0,10 & 0,22 & 0,31 & 0,26 & 0,50 & 1,90 & 2,35 & 2,51 & 3,26 \\
\hline & Nordeste & 0,11 & 0,09 & 0,16 & 0,33 & 0,21 & 0,41 & 1,84 & 1,93 & 2,32 & 2,76 \\
\hline & Sudeste & 0,53 & 0,55 & 0,53 & 0,68 & 0,65 & 1,03 & 2,69 & 2,95 & 4,4 & 5,21 \\
\hline & Sul & 0,50 & 0,53 & 0,55 & 0,70 & 0,55 & 0,89 & 2,59 & 2,98 & 4,19 & 5,1 \\
\hline & Centro-Oeste & 0,37 & 0,28 & 0,36 & 0,58 & 0,38 & 0,80 & 2,18 & 2,87 & 3,29 & 4,53 \\
\hline & Total & 0,39 & 0,39 & 0,41 & 0,57 & 0,48 & 0,81 & 2,38 & 2,68 & 3,66 & 4,45 \\
\hline \multirow{6}{*}{ Rural } & Norte & 0,03 & 0,01 & 0,16 & 0,24 & 0,15 & 0,18 & 1,00 & 1,01 & 1,34 & 1,44 \\
\hline & Nordeste & 0,01 & 0,01 & 0,11 & 0,24 & 0,02 & 0,07 & 0,74 & 0,92 & 0,88 & 1,24 \\
\hline & Sudeste & 0,07 & 0,12 & 0,41 & 0,67 & 0,17 & 0,40 & 1,63 & 1,82 & 2,28 & 3,01 \\
\hline & Sul & 0,13 & 0,05 & 0,52 & 0,71 & 0,14 & 0,19 & 1,42 & 1,59 & 2,21 & 2,54 \\
\hline & Centro-Oeste & 0,08 & 0,09 & 0,42 & 0,69 & 0,26 & 0,36 & 1,65 & 2,12 & 2,41 & 3,26 \\
\hline & Total & 0,05 & 0,04 & 0,27 & 0,42 & 0,11 & 0,18 & 1,14 & 1,28 & 1,57 & 1,92 \\
\hline \multirow{6}{*}{ Total } & Norte & 0,09 & 0,12 & 0,19 & 0,30 & 0,38 & 0,61 & 1,80 & 2,14 & 2,46 & 3,17 \\
\hline & Nordeste & 0,11 & 0,11 & 0,15 & 0,31 & 0,33 & 0,50 & 1,74 & 1,94 & 2,33 & 2,86 \\
\hline & Sudeste & 0,45 & 0,50 & 0,49 & 0,61 & 0,85 & 1,18 & 2,66 & 2,87 & 4,45 & 5,16 \\
\hline & Sul & 0,43 & 0,49 & 0,53 & 0,69 & 0,62 & 1,06 & 2,48 & 2,81 & 4,06 & 5,05 \\
\hline & Centro-Oeste & 0,39 & 0,36 & 0,42 & 0,64 & 0,87 & 1,39 & 2,35 & 3,00 & 4,03 & 5,39 \\
\hline & Total & 0,33 & 0,36 & 0,38 & 0,53 & 0,65 & 0,96 & 2,31 & 2,58 & 3,67 & 4,43 \\
\hline
\end{tabular}

Fonte: IBGE, microdados da POF 2008-2009 e 2017-2018.

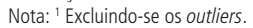




\section{GRÁFICO 1}

POF 2017-2018: razão entre despesa com tributos diretos e renda domiciliar por faixa de SM de 2018, universo de todos os domicílios, média das razões

(Em \%)

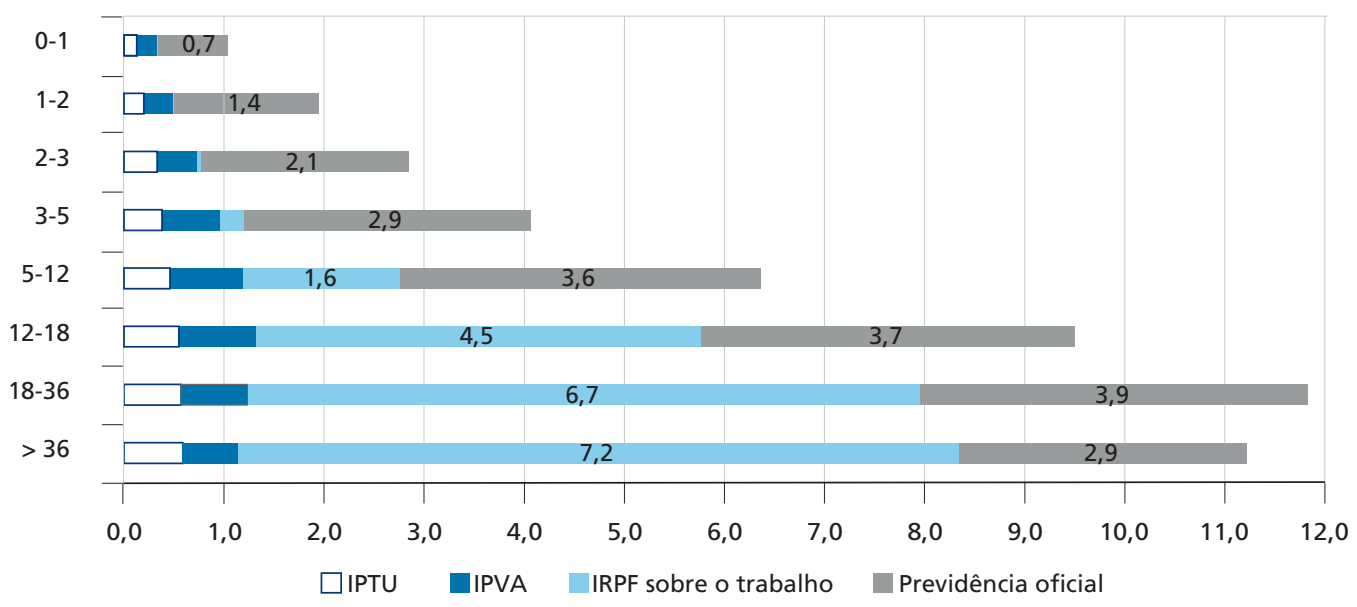

Fonte: IBGE, microdados da POF 2017-2018.

Elaboração do autor.

\subsection{IPTU na renda domiciliar}

De acordo com a tabela 11, a participação do IPTU na renda domiciliar, considerando-se o universo de todos os domicílios (pagantes ou não do imposto), foi progressiva em todos os estratos de renda nas duas POFs. Na POF 2017-2018, o IPTU representou 0,25\% da renda domiciliar entre os 43,1 mais pobres (famílias com renda até $3 \mathrm{SMs}$ ), 0,56\% entre os $9,1 \%$ mais ricos (famílias com renda superior a 12 SMs) e $0,42 \%$ nos demais estratos intermediários.

No entanto, de acordo com a tabela 12, considerando apenas o universo de domicílios que realmente pagaram IPTU (33\% na POF 2008-2009 e 41\% na POF 2017-2018, conforme a tabela 5), ele apresentou estrutura regressiva entre os contribuintes. Na POF 2017-2018, perante os 23\% domicílios com renda até 3 SMs que declararam pagar IPTU, o imposto consumiu 1,2\% da renda domiciliar. Dos $49 \%$ domicílios que declararam pagar IPTU nos estratos intermediários a participação média do IPTU foi de $0,9 \%$ da renda. Por fim, entre os domicílios com renda superior a 12 SMs, o IPTU representou $0,7 \%$ da renda domiciliar. 
Finalmente, de acordo com a tabela 13, na POF 2017-2018, o IPTU representou ao redor de $0,4 \%$ da renda domiciliar de todos os domicílios das capitais, RMs e do interior urbano, mas apenas 0,05\% dos domicílios rurais. Analisando-se os microdados da POF 2017-2018, o IPTU atingiu a participação mais alta no estado de São Paulo, representando $0,75 \%$ da renda domiciliar, enquanto nas regióes Norte e Nordeste o indicador foi ao redor de $0,1 \%$, e nos demais estratos geográficos o indicador variou entre $0,4 \%$ e $0,5 \%$.

\subsection{IPVA na renda domiciliar}

De acordo com a tabela 11, a participação do IPVA na renda domiciliar, considerando-o universo de todos os domicílios (pagantes ou não do imposto), foi progressiva até os $5 \%$ mais ricos nas duas POFs. A acentuada perda de progressividade do IPVA na última POF se deve ao aumento do número de proprietários de automóveis ou motocicletas e consequentemente de contribuintes do imposto (de acordo com a tabela 7 , o indicador aumentou de 42\% para 58\% dos domicílios entre as duas POFs). Em 2017-2018, o IPVA representou cerca de $0,3 \%$ da renda domiciliar entre os $43,1 \%$ mais pobres, $0,7 \%$ da renda entre os $9,1 \%$ mais ricos e $0,7 \%$ da renda nos estratos intermediários.

É importante destacar que a base de cálculo do IPVA, o valor de mercado dos automóveis e motocicletas, tem valores mais discretos que a renda e é esperado que ele seja um imposto com viés regressivo mediante a aplicação de uma alíquota proporcional. Por exemplo, o valor do percentil 95 da renda domiciliar mensal na POF 2017-2018 ( $\mathrm{R} \$ 16.411$ ) é cerca de dezenove vezes superior ao percentil 5. No entanto, essa relação para o valor de mercado de automóveis e motocicletas é provavelmente inferior. Destaca-se que é proibida a progressividade das alíquotas do IPVA, exceto com permissão constitucional, de acordo com vasta jurisprudência sobre impostos reais no Supremo Tribunal Federal.

De acordo com a tabela 12, considerando apenas o universo de domicílios que realmente pagaram IPVA (29\% na POF 2008/2009 e 37\% na POF 2017-2018, conforme a tabela 5), ele apresentou estrutura extremamente regressiva entre os contribuintes. Na última POF, perante as 17\% famílias com renda até 3 SMs que declararam pagar IPVA, o imposto consumiu 2,2\% da renda domiciliar. Nos estratos intermediários, a participação média do IPVA foi de 1,4\% da renda domiciliar, enquanto que nas famílias com renda acima de 12 SMs, o imposto representou 0,9\% da renda 
domiciliar. Esses números destacam a estrutura extremamente regressiva do IPVA entre os contribuintes, e essa tendência tende a aumentar no longo prazo, considerando o universo de todos os domicílios, devido ao o aumento do número de proprietários de veículos nos estratos mais baixos de renda.

Finalmente, de acordo com a tabela 13, na POF 2017-2018, o IPVA representou cerca de $0,3 \%$ da renda de todos os domicílios das regióes Norte e Nordeste e $0,7 \%$ nas regiôes Sul, Sudeste e Centro-Oeste, não havendo diferença significativa nos indicadores de domicílios em capitais e áreas metropolitanas, no interior urbano ou em área rural.

\subsection{IRPF sobre rendimentos do trabalho na renda domiciliar}

De acordo com a tabela 11, a participação do IRPF sobre rendimentos do trabalho na renda domiciliar foi progressiva em todos os estratos de renda nas duas POFs. Em 2017-2018, o indicador foi quase nulo até o percentil 43,1, atingindo 7,2\% da renda domiciliar entre os 1,2\% mais ricos (famílias com renda acima de 36 SMs). Observa-se que, considerando-se todos os domicílios, a participação do IRPF sobre rendimentos do trabalho da POF $2017-2018$ (0,96\%) foi 46\% superior aos da POF 2008-2009 (0,65\%). Esse aumento foi de 92\% nos estratos intermediários (entre os percentis 43,1 e 90,9), evidenciando o problema da falta de correção da tabela do IRPF no período. No entanto, o aumento do indicador foi de apenas $25 \%$ entre os $9,1 \%$ mais ricos.

Pela tabela 12, considerando apenas o universo de domicílios contribuintes do IRPF sobre rendimentos do trabalho (16\% na POF 2008-2009 e 23\% na POF 2017-2018, conforme a tabela 5), ele também apresentou estrutura progressiva em todos os estratos de renda (a tabela não apresenta os dados nos três primeiros estratos devido a baixíssima frequência de pagantes). Na última POF, o imposto representou 2,9\% da renda entre os contribuintes com renda domiciliar entre 5 e 12 SMs e 7,1\% dos contribuintes com renda domiciliar acima de 12 SMs, chegando a atingir apenas 9,1\% da renda dos contribuintes com renda domiciliar acima de 36 SMs, perdendo força no nível de progressividade a partir dos 1,2\% mais ricos. 
Esse indicador de progressividade é corroborado pela base dados das declaraçóes do IRPF disponibilizados pela Receita Federal. ${ }^{30}$ Como analisado por Introíni et al. (2018), a alíquota efetiva do IRPF em 2016 foi progressiva até os contribuintes com renda mensal de $\mathrm{R} \$ 35.200$ (percentil 97,3), ponto onde alcança uma alíquota efetiva sobre rendimentos tributáveis de $11,4 \%,{ }^{31}$ para então começar a ter tendência regressiva e atingir apenas 2,6\% para indivíduos de renda mensal acima de $\mathrm{R} \$ 281.600$ (percentil 99,9). Analisando-se mais os grandes números da Receita Federal para o ano de 2018, os $0,64 \%$ mais ricos (renda acima de $80 \mathrm{SMs}$ ) sofreram uma alíquota efetiva de apenas $3,9 \%$, nível similar aos declarantes com renda de cerca de $7 \mathrm{SMs} .{ }^{32}$ Resultados similares foram achados por Gobetti e Orair (2016) e Silveira, Fernandes e Passos (2019).

Finalmente, de acordo com a tabela 13, na POF 2017-2018, o IRPF representou $1,4 \%$ da renda de todos os domicílios das capitais e RMs, $0,8 \%$ dos domicílios do interior urbano, e apenas $0,2 \%$ dos domicílios rurais. Observa-se que nas regióes Sul, Centro-Oeste e Sudeste, o imposto representou $1,2 \%$ da renda domiciliar, enquanto nas regióes Norte e Nordeste o indicador foi ao redor de 0,5\%. Nas capitais e RMs do Centro-Oeste o imposto teve a participação mais alta $(2,2 \%)$, enquanto no Nordeste rural foi a mais baixa $(0,1 \%)$.

\subsection{Contribuiç̧ão previdenciária na renda domiciliar}

A legislação da contribuição previdenciária do INSS foi desenhada para ser regressiva, visto que, apesar de ser levemente progressiva até o teto previdenciário (alíquotas entre $8 \%$ e $11 \%$ em 2018), há um limite máximo para a contribuição ( $\mathrm{R} \$ 621$ em 2018) que é equivalente a $11 \%$ do teto previdenciário ( $\$$ \$ 5.645,80 em 2018 ou 6,4 SMs na época). No entanto, há exceçôes porque existe as contribuiçóes especiais para a classe extremamente pobre, como $1,2 \%$ da produção rural para trabalhadores rurais e $5 \%$ do SM para contribuintes de baixa renda inseridos no Cadastro Único e sem renda própria com direito apenas a aposentadoria por idade. No entanto, os contribuintes individuais autônomos que queiram se aposentar por tempo de contribuição devem contribuir com uma alíquota majorada de $20 \%$. Por isso, é de esperar que as contribuiçóes

30. Disponível em: <https://bit.ly/2IXB4JW>.

31. Observe que o indicador de tributação efetiva dos top 1\% contribuintes no trabalho de Introíni et al. (2018) $(11,8 \%)$ foi superior ao indicador deste estudo $(9,5 \%)$, porque o primeiro contempla a tributação de aluguéis, ganhos de capital etc. 32. Disponível em: <https://bit.ly/2IXB4JW>. 
previdenciárias tenham menor participação na renda nos estratos mais ricos que nos estratos intermediários, embora o resultado possa ser em tese heterogêneo nos estratos mais baixos.

No caso das contribuições do RPPS, ela fora proporcional até o ano de 2020, onde passou a ser progressiva para servidores civis federais (entre $7,5 \%$ e $22,5 \%$, com possibilidade de também ser progressiva para outras entes). Entre os militares, até 2020, ainda imperava uma alíquota proporcional reduzida de 7,5\%, o qual fora aumentada para $10,5 \%$ a partir de 2021 .

De acordo com a tabela 11, a participaçáo da contribuição previdenciária na renda domiciliar, considerando-se o universo de todos os domicílios (pagantes ou não do imposto), foi progressiva até os 4,6\% mais ricos na POF 2008-2009 e até o 1,2\% mais ricos na POF 2017-2018. Na última POF, a contribuição previdenciária representou em média 1,6\% da renda domiciliar em famílias com renda até $3 \mathrm{SMs}, 3,2 \%$ em famílias com renda entre 2 e 12 SMs, e 3,7\% em famílias com superior a 12 SMs, destacando-se uma redução para 2,9\% perante as famílias com renda superior a 36 SMs.

Já pela tabela 12, considerando apenas o universo de domicílios que realmente pagaram contribuição previdenciária (48\% na POF 2008-2009 e 51\% na POF 2017-2018, conforme a tabela 5), o tributo apresentou estrutura regressiva entre os contribuintes. Na última POF, entre as famílias contribuintes com renda até $1 \mathrm{SM}$ (11\% de pagantes), o tributo consumiu $6,1 \%$ da renda domiciliar, entre as famílias contribuintes com renda superior a 36 SMs ( $85 \%$ de pagantes), 3,4\% da renda domiciliar e nos demais estratos intermediários ele consumiu em média $4,4 \%$ da renda domiciliar.

Finalmente, pela tabela 13, não houve muita diferença entre Grandes Regióes na participação das contribuiçôes previdenciárias na renda domiciliar, ocorrendo mais entre domicílios urbanos e rurais. $\mathrm{Na}$ última $\mathrm{POF}$, a contribuição previdenciária representou 2,8\% da renda domiciliar dos domicílios urbanos, mas apenas 1,3\% dos domicílios rurais. Nas áreas urbanas das regióes Sul, Sudeste e Centro-Oeste, o tributo representou $3 \%$ da renda, enquanto que nas áreas rurais do Norte e Nordeste o indicador foi de $1 \%$. 


\subsection{Tributos diretos na renda domiciliar}

Esta parte analisa a soma da participação na renda domiciliar de todos os tributos diretos analisados por este estudo: IPTU, IPVA, IRPF sobre rendimentos do trabalho e contribuição previdenciária, por estrato de renda e por estrato geográfico. De acordo com a tabela 11, a participaçáo dos tributos diretos na renda domiciliar, considerando-se o universo de todos os domićlíios, foi progressiva em todos os estratos na POF 2008-2009 e progressiva até o percentil 98,8 na POF 2017-2018. A perda de progressividade entre os top $1 \%$ em relação ao estrato anterior, onde os tributos diretos foram equivalentes a $11,2 \%$ da renda domiciliar, foi decorrente da regressividade nesta faixa do IPVA, contribuição previdenciária e em menor escala do IPTU. Nos demais estratos, a participação dos tributos diretos foi bem progressiva, começando em apenas $1 \%$ da renda entre as famílias com renda até 1 SM e terminando em 11,8\% entre 18 e 36 SMs. Isso mostra a progressividade dos tributos diretos ainda náo tem força suficiente atingir o topo mais extremo. Isso pode ser mais bem visualizado no gráfico 1 .

Além disso, de acordo com os estratos geográficos da tabela 13, na POF 2017-2018, os tributos diretos representaram $5,3 \%$ da renda domiciliar de todos os domicílios das capitais e RMs, 4,5\% dos domicílios do interior urbano, mas apenas 1,9\% dos domicílios rurais. Os dados da POF 2008-2009, foram um pouco mais baixos em todos os estratos geográficos. Observa-se que nas regiōes Sul, Sudeste e Centro-Oeste, os tributos diretos atingiram a participaçáo de $5,2 \%$ da renda domiciliar, enquanto que nas regióes Norte e Nordeste o indicador foi de cerca de 2,9\%. O indicador mais alto de tributaçáo direta foi verificado nas capitais e RMs da regiáo Centro-Oeste (6,7\%).

\section{CONCLUSÃo}

Essa seção final realiza um diagnóstico dos dados levantados por esse estudo, faz sugestóes de políticas para reduzir o grau de regressividade dos tributos diretos no topo extremo da distribuição de renda - sendo essa a principal conclusão deste estudo, e por fim, tece as consideraçóes finais, apontando a necessidade de estudos adicionais, e o aprimoramento das pesquisas e uma maior publicidade e detalhamento das bases de dados. 
O estudo mostrou que o aumento da arrecadação tributária direta no Brasil entre 2008-2009 e 2017-2018 pelo IPTU, IPVA, IRPF sobre rendimentos do trabalho e contribuição previdenciária ocorreu devido ao maior número de contribuintes e não através de uma tributação mais progressiva. Quando se analisa apenas o peso da carga tributária na renda dos domicílios contribuintes destes impostos, a regressividade se mostrou mais explícita. Apesar do menor número de contribuintes nos estratos mais baixos de renda, seja devido as isençóes legais, a inadimplência ou a informalidade, o desenho da tributação direta no Brasil tende a ser regressivo no topo extremo.

O IPTU teve um aumento significativo de contribuintes, passando de $33 \% \mathrm{em}$ 2008-2009 para 41\% em 2017-2018. No entanto, ele apresentou estrutura regressiva entre contribuintes. Em 2017-2018,, perante as 23\% famílias com renda até 3 SMs que declararam pagar IPTU, o imposto consumiu $1,2 \%$ da renda domiciliar, enquanto que em famílias com renda superior a $36 \mathrm{SMs}$, ele representou ao redor de $0,7 \%$ da renda.

O IPVA foi de longe o imposto com estrutura mais regressiva, devido ao aumento do número de motocicletas e automóveis nos estratos de renda mais baixos, onde inclusive são usados como instrumento de trabalho. Se contrapondo ao nível de renda, o valor de mercado dos veículos, tem variação discreta e as alíquotas proporcionais acentuam a regressividade natural do IPVA. O imposto representou 2,2\% da renda das famílias contribuintes com renda até 3 SMs, mas apenas $0,9 \%$ nas famílias com renda superior a 36 SMs.

O IRPF sobre rendimentos do trabalho apresentou estrutura progressiva, mas tendendo a reduzir sua progressividade no topo extremo (1,2\% mais ricos), acompanhando os mesmos resultados de outros estudos que utilizaram a base de declaração do IRPF. Nos demais estratos ele foi progressivo: nos domicílios brasileiros com renda entre 5 e 12 SMs o imposto representou 1,6\% da renda domiciliar, entre 12 e 18 SMs, 4,5\% da renda, entre 18 e 36 SMs, 6,7\% da renda, e entre os 1,2\% mais ricos, $7,2 \%$ da renda. Em nível internacional, este percentual ainda é muito baixo. Por exemplo, nos Estados Unidos, os 1\% mais ricos sofreram uma alíquota efetiva do imposto de renda de 26,8\% (York, 2020).

O desenho da legislação da contribuição previdenciária tem poucos elementos progressivos e muitos elementos regressivos. Por exemplo, no RGPS, a legislação 
permite contribuiçóes favoráveis para segurados rurais e para os de baixa renda (com limitaçôes), porém a base de cálculo é limitada ao valor do teto previdenciário, fazendo com que indivíduos no topo extremo do setor privado contribuam com o mesmo valor que indivíduos com renda de 6 SMs. Além disso, autônomos que desejem se aposentar por tempo de contribuição devem pagar uma alíquota majorada de $20 \%$. De fato, o estudo mostrou que a contribuição previdenciária correspondeu a $6,1 \%$ da renda perante os contribuintes mais pobres de renda até $1 \mathrm{SM}$, e 3,4\% perante os 1,2\% mais ricos. Nos demais estratos intermediários, o indicador médio foi de 4,5\%.

Essas considerações finais também apresentam algumas sugestões, não exaustivas, para aumentar a progressividade dos tributos diretos, principalmente no topo extremo. No caso do IPTU, atualmente as prefeituras têm grande dificuldade para atualizar as avaliaçóes imobiliárias (contidas nas plantas genéricas de valores) que são a base de cálculo do imposto. Devido a Súmula no 160/1996 do Supremo Tribunal de Justiça, é necessária uma lei municipal (com aprovação na Câmara de Vereadores) para atualização dos valores venais acima da inflação. O mercado imobiliário é dinâmico, onde áreas se valorizam fortemente, enquanto outras se desvalorizam. Se os municípios pudessem mais facilmente atualizar os valores venais, através, por exemplo, de decreto municipal ou houvesse uma previsão legal estipulando um período máximo entre as atualizações, os valores venais dos imóveis mais valorizados estariam mais próximos do mercado, afetando os contribuintes mais ricos (De Cesare et al., 2020). Há muitos casos de municípios que estão ou estavam há mais de vinte anos sem atualização dos valores venais. Por exemplo, Rio de Janeiro (1997-2017), Manaus (1983-2011), Recife (1991-2015) e João Pessoa (sem atualizar desde 1972). Além disso, a progressividade das alíquotas do IPTU é permitida desde a Emenda Constitucional no 29/2000 e os municípios têm ampla autonomia para aplicá-las. Carvalho Junior (2018b) estimou que $25 \%$ das maiores cidades brasileiras adotam um sistema de IPTU com alíquota progressiva, representando uma tendência crescente.

No IPVA, o imposto se mostrou altamente regressivo e poderia até ser eliminado do sistema tributário brasileiro, já que os veículos são pesadamente taxados pelo Imposto sobre Circulação de Mercadorias e Serviços (ICMS) e Imposto sobre Produtos Industrializados (IPI). No entanto, os governos estaduais têm apresentado grande deficit financeiro e isso traria enorme impacto nas contas públicas (o IPVA tem representado entre 5\% e $8 \%$ das receitas dos estados do Centro-Sul). Algumas 
medidas, no entanto, poderiam ser adotadas para mitigar a regressividade do imposto. A primeira seria a permissão legal em se tributar embarcaçōes e aeronaves particulares (o Supremo Tribunal Federal declarou inconstitucional em julgamento realizado em 2008). ${ }^{33}$ A segunda seria a permissão legal para aplicação de alíquotas progressivas, onde seria necessária a aprovação de uma Emenda Constitucional. Alternativamente, os próprios governos estaduais poderiam aumentar a alíquota proporcional, para um valor, por exemplo, de $6 \%$, e oferecer um desconto fixo no imposto a pagar para todos os contribuintes, mecanismo que garantiria certa progressividade. Terceiro, os governos estaduais poderiam isentar o IPVA das motocicletas de até determinado valor.

Sobre o IRPF, a base de dados da Receita Federal mostra que o imposto é progressivo até os $2 \%$ mais ricos. Recentemente foram publicados numerosos estudos que atestam a regressividade do IRPF no topo extremo, apontando as principais causas deste cenário e fazendo proposições de política. ${ }^{34}$ Este estudo não aprofunda essa questão, apenas levanta simplificadamente os principais pontos de consenso acadêmico dos estudos sobre redução da desigualdade via tributação. Primeiramente, a isenção do IRPF sobre lucros e dividendos, bem como a dedução para juros sobre o capital próprio deveriam ser eliminadas. Esses rendimentos devem seguir as mesmas regras de tributação dos salários, inclusive com recolhimento na fonte. Segundo, a dedução sem limite de valor com despesas médicas deve ser limitada a um valor fixo (conforme ocorre com a dedução para gasto com educação), de acordo com a faixa etária do contribuinte, de forma a evitar gastos perdulários com despesas médicas de contribuintes de alta renda. Terceiro, a faixa de isenção do IRPF pode ser aumentada, mas alíquotas adicionais devem ser instituídas até o valor de, por exemplo, 45\%. Juntamente com o fim das isençóes citadas anteriormente, isso provavelmente proporcionaria uma alíquota efetiva de 20\%-25\% para contribuintes no topo extremo, no lugar dos atuais 3\%. Quarto, o Imposto sobre Grandes Fortunas deveria ser instituído e cobrado juntamente com a Declaração de Ajuste Anual do IRPF com alíquotas progressivas entre 1\% e 2,5\% no que exceder o patrimônio líquido global de, por exemplo, R \$ 2 milhóes. Segundo a Secretaria da Receita Fereral, ${ }^{35}$ o patrimônio médio dos contribuintes com renda mensal entre 60 e 80 SMs foi de R 3 milhóes em 2018, e como o imposto só seria

33. Disponível em: <https://stf.jusbrasil.com.br/jurisprudencia/757568/recurso-extraordinario-re-379572-rj>. 34. Para um aprofundamento, consultar diversos capítulos do livro de Fagnani (2018), além de Orair e Gobetti (2016). 35. Disponivel em: <https://bit.ly/2IXB4JW>. 
cobrado ao que excedesse $\mathrm{R} \$ 2$ milhóes, esta faixa de renda enfrentaria uma cobrança média anual, não desprezível, de cerca de $\mathrm{R} \$ 10.000$.

No caso da contribuição previdenciária, segundo o art. 195 da Constituição Federal de 1988 "A seguridade social será financiada por toda a sociedade", ${ }^{36}$ mas contraditoriamente o mesmo artigo prevê que ela seja financiada por rendimentos pessoais derivados apenas do trabalho. Primeiramente, uma reforma tributária deveria permitir o financiamento da seguridade social por todos os tipos de rendimentos recebidos pela pessoa física, tendo base de cálculo similar ao IRPF (isso ocorre nos sistemas da Dinamarca e África do Sul, por exemplo). Segundo, partindo do princípio de solidariedade no financiamento da seguridade social, deveria ser instituída uma Contribuição Solidariedade para a Seguridade Social (CSSS), desvinculada de qualquer contrapartida em benefício previdenciário, e com alíquotas progressivas, por exemplo, entre $1 \%$ e $15 \%$, sobre todos os tipos e valores de rendimentos, destinadas a financiar o deficit previdenciário e aumentar o alcance da seguridade social. A CSSS seria cobrada cumulativamente com a atual contribuição previdenciária que é vinculada ao benefício previdenciário, podendo haver algum mecanismo que não permitisse uma tributaçáo efetiva superior a 50\% da renda anual do contribuinte, quando combinados o IRPF, a contribuição previdenciária e a CSSS.

O artigo destacou a perda de progressividade dos tributos diretos no topo extremo de renda e fez algumas recomendaçóes de política para o alimentar o debate da reforma tributária baseada em uma política de médio prazo que torne o sistema tributário brasileiro realmente progressivo. Evidentemente estudos adicionais devem ser elaborados, principalmente com o uso de base de dados mais detalhadas. Recomenda-se que a base com microdados das declaraçóes do IRPF seja disponibilizada ao público (com a omissão das informaçóes pessoais dos contribuintes) de forma que se possa realizar estudos mais detalhados da distribuição da renda e do patrimônio. Além disso, o intervalo de nove anos entre as duas últimas POFs, 2008-2009 e 2017-2018 foi muito elevado em comparação a outros países e poderia ser revisto para ser realizado a cada cinco anos, e com o aumento do número de domicílios de alta renda na amostra (na última POF houve apenas 437 domicílios com renda superior a 36 SMs). As POFs também deveriam conter o valor de mercado dos imóveis de propriedade das famílias (apenas o aluguel da residência principal é contabilizado, de forma imputada

36. Disponível em: <https://www2.senado.leg.br/bdsf/bitstream/handle/id/518231/CF88_Livro_EC91_2016.pdf>. 
ou não), o valor de mercado dos automóveis (apenas a compra do automóvel no período da pesquisa é informada), e o valor dos ativos financeiros (apesar da usual omissão deste tipo de patrimônio). Porém, o ponto mais importante, seria a próxima POF passar a desagregar as deduçóes de rendimentos náo relacionados ao trabalho habitual, de forma que se possa extrair diretamente os dados do IRPF e da contribuição previdenciária sobre rendimentos de capital, aposentadorias e pensóes, de forma a se ter uma estimação mais precisa da distribuição da carga tributária pela POF.

\section{REFERÊNCIAS}

AGUIAR, M. A.; BILS, M. Has Consumption Inequality Mirrored Income Inequality? Cambridge (MA): National Bureau of Economic Research, 2011. (Working Paper, 16807).

ALMEIDA, A. N. de. Elasticidades renda e preços: análise do consumo familiar a partir dos dados da POF 2008/2009. São Paulo: Editora USP, 2011. (Texto para Discussão Nereus, n. 4).

CARVALHO JUNIOR, P. H. B. de. Aspectos distributivos do IPTU e do patrimônio imobiliário das famílias brasileiras. Rio de Janeiro: Ipea, 2009. (Texto para Discussão, n. 1417).

Imposto sobre a Propriedade de Veículos Automotores (IPVA). In: FAGNANI, E. (Org.). A reforma tributária necessária: diagnóstico e premissas. Brasília: Anfip; Fenafisco; São Paulo: PPS, 2018a. p. 426-435. Disponível em: <http://bit.ly/2PNq5nR>.

Panorama do IPTU: um retrato da administração tributária em 53 cidades selecionadas. Rio de Janeiro: Ipea, 2018b. (Texto para Discussão, n. 2419).

DE CESARE, C. M. et al. IPTU e a PEC 110/2019 (reforma tributária): teoria, prática, insensatez e retrocesso. Revista da ESDM, v. 6, n. 11, p. 72-93, 2020.

DINIZ, B. P. C. et al. As pesquisas de orçamentos familiares no Brasil. In: SILVEIRA, F. G. et al. (Org.). Gasto e consumo das famílias brasileiras contemporâneas. Brasília: Ipea, 2007. p. 17-74.v. 2.

FAGNANI, E. (Org.). A reforma tributária necessária: diagnóstico e premissas. Brasília: Anfip; Fenafisco; São Paulo: PPS, 2018. Disponível em: <http://bit.ly/2PNq5nR>.

GOBETTI, S. W.; ORAIR, R. O. Progressividade tributária: a agenda negligenciada. Rio de Janeiro: Ipea, 2016. (Texto para Discussão, n. 2190).

HOFFMANN, R. Elasticidades-renda das despesas e do consumo físico de alimentos no Brasil metropolitano em 1995-1996. In: SILVEIRA F. G. et al. (Org.). Gasto e consumo das famílias brasileiras contemporâneas. Brasília: Ipea, 2006. p. 197-212. v. 1. 
Elasticidades-renda das despesas e do consumo de alimentos no Brasil em 2002-2003. In: SILVEIRA, F. G. et al. (Org.). Gasto e consumo das famílias brasileiras contemporâneas. Brasília: Ipea, 2007. p. 463-484. v. 2.

INTROÍNI, P. G. H. et al. Tributação sobre a renda da pessoa física: isonomia como princípio fundamental de justiça fiscal. In: FAGNANI, E. (Org.). A reforma tributária necessária: diagnóstico e premissas. Brasília: Anfip; Fenafisco; São Paulo: PPS, 2018. p. 245-280.

KOIJEN, R.; NIEUWERBURGH, S. van; VESTMAN, R. Judging the quality of survey data by comparison with "truth" as measured by administrative records: evidence from Sweden. In: CARROLL, C. D.; CROSSLEY, T. F.; SABELHAUS, J. (Ed.). Improving the measurement of consumer expenditures. London: University of Chicago Press, 2015. p. 308-346. v. 74.

MEYER, B. D.; MOK, W. K. C.; SULLIVAN, J. X. The under-reporting of transfers in household surveys: its nature and consequences. Cambridge, United States: NBER, 2009. (Working Paper, n. 15181).

ROSSIGNOLO, D. Taxes, expenditures, poverty and income distribution in Argentina. New Orleans: CEQ Institute, 2016. (Working Paper, n. 45).

SILVEIRA F. G. et al. (Org.). Gasto e consumo das famílias brasileiras contemporâneas. Brasília: Ipea, 2006. v. 1.

(Org.). Gasto e consumo das famílias brasileiras contemporâneas. Brasília: Ipea, 2007. v. 2.

SILVEIRA, F. G. et al. Impactos redistributivos das transferências públicas monetárias e da tributaçáo direta: evidências com a POF 2017-2018. Brasília: Ipea, 2020. (Nota Técnica, n. 89).

SILVEIRA, F. G.; FERNANDES, R. C.; PASSOS, L. Benefícios fiscais do imposto sobre a renda da pessoa física e seus impactos redistributivos. Brasília: Ipea, 2019. (Nota Técnica, n. 57).

SURICO, P.; TREZZI, R. Consumer spending and property taxes. Journal of the European Economic Association, v. 17, n. 2, p. 606-649, 2019.

YORK, E. Summary of the latest federal income tax data: February 2020 update. Washington: Tax Foundation, 2020. (Fiscal Fact, n. 697).

\section{BIBLIOGRAFIA COMPLEMENTAR}

FORMENTI, M. Mean of ratios or ratio of means: statistical uncertainty applied to estimate multiperiod probability of default. Castellanza: Università Carlo Cattaneo Press, 2014. 

Ipea - Instituto de Pesquisa Econômica Aplicada

Assessoria de Imprensa e Comunicação

\section{EDITORIAL}

Coordenação

Reginaldo da Silva Domingos

\section{Supervisão}

Carlos Henrique Santos Vianna

Revisão

Bruna Oliveira Ranquine da Rocha

Carlos Eduardo Gonçalves de Melo

Elaine Oliveira Couto

Lis Silva Hall

Mariana Silva de Lima

Marlon Magno Abreu de Carvalho

Vivian Barros Volotão Santos

Laysa Martins Barbosa Lima (estagiária)

\section{Editoração}

Aline Cristine Torres da Silva Martins

Mayana Mendes de Mattos

Mayara Barros da Mota (estagiária)

\section{Capa}

Danielle de Oliveira Ayres

Flaviane Dias de Sant'ana

\section{Projeto Gráfico}

Renato Rodrigues Bueno

The manuscripts in languages other than Portuguese published herein have not been proofread.

\section{Livraria Ipea}

SBS - Quadra 1 - Bloco J - Ed. BNDES, Térreo.

70076-900 - Brasília - DF

Fone: (61) 2026-5336

Correio eletrônico: livraria@ipea.gov.br 

Composto em adobe garamond pro 12/16 (texto) Frutiger 67 bold condensed (títulos, gráficos e tabelas)

Rio de Janeiro-RJ 



\section{Missão do Ipea}

Aprimorar as políticas públicas essenciais ao desenvolvimento brasileiro por meio da produção e disseminação de conhecimentos e da assessoria ao Estado nas suas decisões estratégicas.

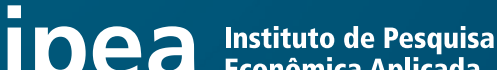

